\title{
Organic carbon densities and accumulation rates in surface sediments of the North Sea and Skagerrak
}

\author{
Markus Diesing, Terje Thorsnes, and Lilja Rún Bjarnadóttir \\ Geological Survey of Norway, P.O. Box 6315, Torgarden, 7491 Trondheim, Norway \\ Correspondence: Markus Diesing (markus.diesing@ngu.no)
}

Received: 24 September 2020 - Discussion started: 6 October 2020

Revised: 18 February 2021 - Accepted: 18 February 2021 - Published: 24 March 2021

\begin{abstract}
Continental shelf sediments are places of both rapid organic carbon turnover and accumulation, while at the same time increasingly subjected to human-induced disturbances. Recent research suggests that shelf sediments might have a role to play as a natural climate solution, e.g. by storing organic carbon if left undisturbed from anthropogenic activity. However, we have an incomplete understanding about the centres of organic carbon accumulation and storage on continental shelves. To better constrain the rate of accumulation and the mass of organic carbon that is stored in sediments, we developed and applied a spatial modelling framework that allows us to estimate those quantities from sparse observations and predictor variables known or suspected to influence the spatial patterns of these parameters. This paper presents spatial distribution patterns of organic carbon densities and accumulation rates in the North Sea and Skagerrak. We found that organic carbon stocks and accumulation rates are highest in the Norwegian Trough, while large parts of the North Sea are characterised by low stocks and zero net accumulation. The total stock of organic carbon that is stored in the upper $0.1 \mathrm{~m}$ of sediments amounted to $230.5 \pm 134.5 \mathrm{Tg} \mathrm{C}$, of which approximately $26 \%$ is stored in the Norwegian Trough. Rates of organic carbon accumulation in the Norwegian Trough are comparable with those reported from nearby fjords. We provide baseline datasets that could be used in marine management, e.g. for the establishment of "carbon protection zones". Additionally, we highlight the complex nature of continental shelves with zones of rapid carbon cycling and accumulation juxtaposed, which will require further detailed and spatially explicit analyses to constrain sedimentary organic carbon stocks and accumulation rates globally.
\end{abstract}

\section{Introduction}

Marine sediments are an important sink for organic carbon (OC) on Earth, with estimates of OC burial in marine sediments ranging from $126 \mathrm{Tg} \mathrm{Cyr}^{-1}$ (Berner, 1982) to $350 \mathrm{Tg} \mathrm{C} \mathrm{yr}^{-1}$ (Keil, 2017). The major hotspots for OC burial in the global ocean are the coastal margins (Bianchi et al., 2018). Burdige (2007) estimated that $80 \%\left(248 \mathrm{Tg} \mathrm{C} \mathrm{yr}^{-1}\right)$ of all OC buried in marine sediments is occurring in continental margin sediments. However, other estimates do also exist (Bauer et al., 2013; Duarte et al., 2005; Hedges and Keil, 1995), ranging from 45.2 to $300{\mathrm{Tg} \mathrm{C} \mathrm{r}^{-1}}^{-1}$, and budgets are generally not well constrained (Burdige, 2007). Estimates of the amount of OC stored in marine surface sediments also vary considerably, ranging from $87 \mathrm{PgC}$ (Lee et al., 2019) via $168 \mathrm{Pg} \mathrm{C}$ (LaRowe et al., 2020) to $3117 \mathrm{Pg} \mathrm{C}$ (Atwood et al., 2020). Such differences can be attributed only partly to differences in the reference depths being considered, ranging from $0-5 \mathrm{~cm}$ (Lee et al., 2019) to the bioturbated Holocene layer, which is assumed to be $0-10 \mathrm{~cm}$ (LaRowe et al., 2020) or $0-1 \mathrm{~m}$ (Atwood et al., 2020).

In recent years, attempts have been made to construct carbon budgets for entire continental shelf systems. However, these studies have not included spatially explicit estimates of OC stock and burial (Fennel et al., 2019; Najjar et al., 2018) or concluded that both stocks and burial rates were associated with considerable uncertainty (Legge et al., 2020).

Given the importance of continental margins in OC cycling, it is therefore of great importance to develop adequate methods that better constrain stocks, flows, and budgets of OC and quantify the uncertainty of the predictions. In particular, spatially explicit methods that predict the variation of OC in space by means of geostatistics or machinelearning spatial prediction are promising, and much can be 
learnt from related terrestrial disciplines such as digital soil mapping (Hengl et al., 2014, 2017; McBratney et al., 2003). Recent studies appear to prefer machine-learning approaches over geostatistical approaches (Seiter et al., 2004) due to their performance, flexibility, and generality (Hengl et al., 2018), and estimates of OC stored in marine sediments at a global (Atwood et al., 2020; Lee et al., 2019) and sea-basin scale (Diesing et al., 2017; Wilson et al., 2018) have been derived. However, no spatially explicit estimates of OC accumulation and burial rates exist to our knowledge.

It is important to stress the difference between OC burial and $\mathrm{OC}$ accumulation here. Burial is the deposition of OC below the zone of active degradation (Keil, 2015). OC degradation in surficial seafloor sediments happens via various processes including aerobic respiration, denitrification, manganese reduction, iron reduction, sulfate reduction, and methanogenesis (Berner, 1980). Burial thus is the removal of OC from the active carbon cycle, and the burial rate can be expressed as the product of sediment accumulation and OC content at the depth below which no further degradation of OC occurs (Middelburg, 2019). It is, however, difficult to determine that depth. Various depth horizons have been used, e.g. the lower boundary of the sulfate reduction zone (Jørgensen et al., 1990), $15 \mathrm{~cm}$ (Hartnett et al., 1998), and $10 \mathrm{~cm}$ (Bakker and Helder, 1993). OC accumulation rates, however, can be calculated for any specific depth interval of the sediment column. Due to the difficulties of determining the relevant depth to estimate burial rates and the scarcity of burial rate data, we decided to estimate $\mathrm{OC}$ accumulation rates instead.

Well-constrained estimates of OC stocks and accumulation rates are also required from a marine management perspective. OC stocks are a measure of the vulnerability potential, while accumulation rates are a measure of the mitigation potential (Jennerjahn, 2020). The potential of so-called "Blue Carbon" ecosystems (mangroves, salt marshes, seagrass meadows, and potentially macroalgae; Krause-Jensen and Duarte, 2016) to sequester and store OC is an important ecosystem service that has been highlighted in recent years (Duarte et al., 2005; Mcleod et al., 2011; Nellemann et al., 2009). More recently, it has been shown that fjord (Smeaton et al., 2016, 2017) and continental shelf sediments (Diesing et al., 2017) harbour considerable amounts of OC. In the United Kingdom, the shelf sediment stock (205 Tg C) accounts for $93 \%$ of OC stored in coastal and marine habitats (Luisetti et al., 2019) and outweighs combined seagrass and salt marsh stocks ( $13.4 \mathrm{Tg} \mathrm{C}$ ) by a factor of $\approx 15$. In Namibia, the marine sediment OC stock is estimated to be larger than the soil OC stock (Avelar et al., 2017). Determining national carbon stocks is essential to understand the potential vulnerability of those stocks to human activities; however, national assessments for greenhouse gas reporting do not account for marine stocks such as organic carbon stored in shelf sediments (Avelar et al., 2017). In Norway, the government has underlined the significance of OC uptake by marine vegeta- tion, but OC accumulation in marine sediments is currently not considered (Anonymous, 2013). Consequently, a question has been raised about whether those stocks should be considered part of national carbon accounting and potential greenhouse gas mitigation strategies and be subject to management against human-induced disturbance (Avelar et al., 2017). The socio-economic importance of marine carbon storage has recently been assessed in a scenario analysis of increased human and climate pressures over a 25 -year period. It was estimated that damage costs of up to USD 12.5 billion from carbon release linked to disturbance of coastal (areal loss of seagrass habitats, sediment OC loss from salt marshes) and shelf sea sediment (resuspension by bottom contact fishing) carbon stores could arise in the United Kingdom (Luisetti et al., 2019). However, the transboundary nature of carbon flows in the marine environment poses significant challenges for carbon accounting and requires new guidance and governance frameworks to manage these stocks (Luisetti et al., 2020).

Marine protected areas (MPAs) might be a suitable management measure to effectively protect the carbon storage ecosystem service of Blue Carbon ecosystems against human pressures (Zarate-Barrera and Maldonado, 2015) by slowing, halting, or reversing the trend of degradation and loss of, for example, seagrass and mangrove ecosystems. In Indonesia, MPAs reduced mangrove loss by about $140 \mathrm{~km}^{2}$ and avoided emissions of $13 \mathrm{Tg} \mathrm{CO}$ equivalent between 2000 and 2010 (Miteva et al., 2015). Further offshore, demersal fishing is an important and widespread pressure on continental shelf seabed habitats (Amoroso et al., 2018; Halpern et al., 2008). Chronic demersal fishing has negative impacts on benthic biomass, production, and species richness, and it is leading to shifts in the composition of communities (Hiddink et al., 2006, 2017; Jennings et al., 2001; Tillin et al., 2006). The impact of demersal fishing on the biogeochemistry of the seafloor and OC storage is less well understood. Several studies show lower OC contents in surface sediments of trawled areas (Bhagirathan et al., 2010; Martín et al., 2014b; Paradis et al., 2019, 2020; Pusceddu et al., 2014), while others report higher OC contents, presumably due to fertilisation brought about by resuspension or uplifting of OC from deeper layers caused by trawling (Palanques et al., 2014; Pusceddu et al., 2005). In the short term, demersal-fishing-induced sediment disturbance stimulates OC mineralisation in cohesive sediments, likely due to the enhanced decomposition of previously buried refractory OC (van de Velde et al., 2018). In the long term, the expected result of repeated and vigorous sediment mixing due to demersal fishing is a general impoverishment in OC (Martín et al., 2014a). Given the large areas affected $\left(\approx 10 \times 10^{6} \mathrm{~km}^{2}\right)$ and the amount of sediment being resuspended $\left(\approx 22 \mathrm{Pg} \mathrm{yr}^{-1}\right.$ ) globally (Oberle et al., 2016), it is likely that the impact of demersal fishing on shelf sediment OC storage is substantial. Chronic seabed disturbance by demersal fishing might have a sizeable impact on the carbon cycle in cohesive sediments on continental shelves by 
keeping coastal seabed biogeochemistry in a transient state, which translates into reduced $\mathrm{OC}$ accumulation rates (van de Velde et al., 2018). Establishment of MPAs protecting against demersal fishing could not only facilitate the recovery of benthic species but also promote longer-term carbon uptake by seabed ecosystems through increased biomass, as well as prevent further loss of OC stored in sediments (Roberts et al., 2017).

The North Sea and Skagerrak are among the most intensively researched regional seas with a wealth of data available for reuse. At the same time, they are the most heavily impacted by human activities (Halpern et al., 2008). This makes the area ideal for our study which has the objectives to estimate OC stocks and accumulation rates of surface sediments in a regional sea that is impacted by human activities. These estimates will be accompanied by assessments of uncertainty in the predictions. With the help of these predictions, the following research questions will be addressed:

1. What is the importance of seafloor sediment OC stocks relative to other OC stocks?

2. Where are the centres of OC accumulation in the North Sea and Skagerrak?

3. Based on the previous results, can we differentiate between different zones of OC processing at the seafloor?

4. What are possible implications for marine management?

\section{Regional setting}

The study site encompasses the North Sea and Skagerrak regional seas as defined by the International Hydrographic Organization (1953). The surface areas of the North Sea and Skagerrak are approximately 526000 and $32000 \mathrm{~km}^{2}$, respectively. The seafloor in the study site is mostly shallow and flat, generally deepening from south to north (Fig. 1). The most prominent morphological feature is the Norwegian Trough, which follows the coast of southern Norway and reaches water depths of nearly $700 \mathrm{~m}$ in the Skagerrak. It forms a major accumulation area for fine-grained material (Eisma and Kalf, 1987; Van Weering, 1981). Large parts of the continental shelf outside the Norwegian Trough are erosional or non-depositional in nature (de Haas et al., 1997), with limited sedimentation occurring in the German Bight, the Elbe palaeo-valley, Oyster Ground, Inner Silver Pit, Outer Silver Pit, and Devil's Hole (Eisma and Kalf, 1987; de Haas et al., 1997). Previous studies (de Haas et al., 1997, 2002; de Haas and van Weering, 1997) have indicated that most of the OC accumulation occurs in the Norwegian Trough $\left(\approx 1 \mathrm{TgC}^{-1}\right)$, while OC accumulation in the remaining area is low $\left(\approx 0.1 \mathrm{Tg} \mathrm{C} \mathrm{yr}^{-1}\right)$.

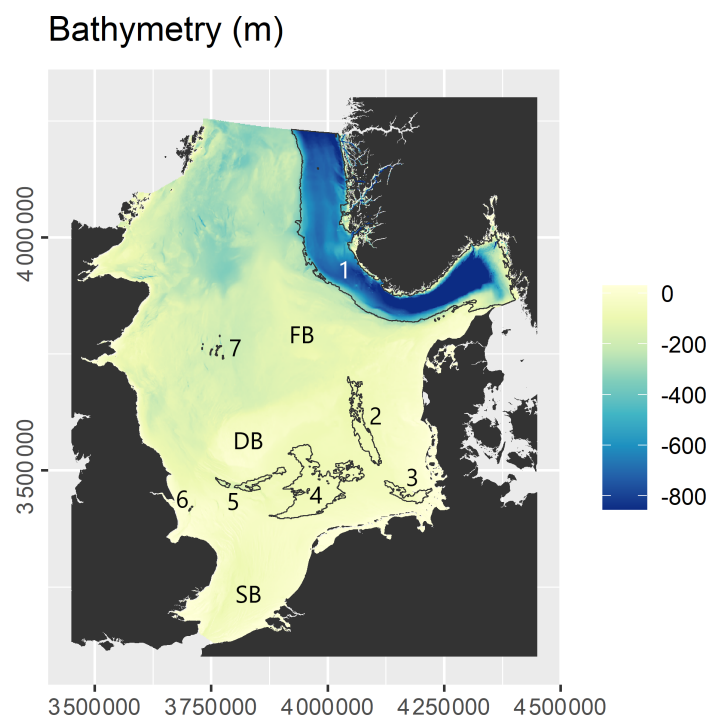

Figure 1. Overview of the study site. Letters refer to localities: DB - Dogger Bank; FB - Fisher Bank; SB - Southern Bight. Numbers refer to areas of sediment deposition: 1 - Norwegian Trough; 2 Elbe palaeo-valley; 3 - German Bight; 4 - Oyster Ground; 5 - Outer Silver Pit; 6 - Inner Silver Pit; 7 - Devil's Hole. Refer to Sect. 3.2 for the delineation of areas of sediment deposition.

\section{Data}

\subsection{Response variables}

\subsubsection{Linear sedimentation rate}

Linear sedimentation rate $(\omega)$ (measured in $\mathrm{cm} \mathrm{yr}^{-1}$ ) is used here synonymously with sediment accumulation rate. Data were initially sourced from the EMODnet-Geology portal (https://www.emodnet-geology.eu/, last access: 5 February 2019), which provides a collation of values from the literature across European sea basins. The dataset was limited to the study site and sedimentation rates based on ${ }^{210} \mathrm{~Pb}$, to ensure a consistent integration timescale (Jenkins, 2018). Based on a half-life of approximately 22 years, the associated integration time is roughly 100 years (Jenkins, 2018). Data from Zuo et al. (1989) were excluded as these were deemed unreliable (de Haas et al., 1997).

The reported sedimentation rate data focussed on accumulation areas like the Norwegian Trough (Fig. 2). However, to be able to spatially predict sedimentation rates across the study site it is necessary to include data from areas of erosion and non-deposition, which predominate in the North Sea. Therefore, the data by de Haas et al. (1997) were also included. This provided less than 20 data points of zero netsedimentation, which was still deemed insufficient. Additionally, pseudo-observations (Hengl et al., 2017) were also included. Pseudo-observations are "virtual" samples that are placed in undersampled areas and for which the value of the response variable can be assumed with high certainty. Hengl 
et al. (2017) cite $0 \%$ soil OC in the top $2 \mathrm{~m}$ of active sand dunes as an example. Mitchell et al. (2021) placed pseudosamples in areas of bedrock outcropping at the seabed when predicting sedimentation rates in the Baltic Sea. The placement of pseudo-observations was restricted to areas of erosion and non-deposition (based on the sedimentary environment layer, as described in Sect. 3.2), for which a sedimentation rate of $0 \mathrm{~cm} \mathrm{yr}^{-1}$ could be assumed. The pseudoobservations were placed randomly to avoid human bias. Some of the sedimentation rate values from non-depositional areas reported by de Haas et al. (1997) and van Weering et al. (1993) appeared too high, and after a review of the ${ }^{210} \mathrm{~Pb}-$ profiles four of them were set to $0 \mathrm{~cm} \mathrm{yr}^{-1}$ due to low ${ }^{210} \mathrm{~Pb}$ activities and indistinct decreases with depth. The full dataset used for subsequent modelling is shown in Fig. 2 and provided as Table S1 in the Supplement.

\subsubsection{Organic carbon density}

Previous studies have predicted OC content and sediment porosity separately to calculate OC stocks (Diesing et al., 2017; Lee et al., 2019; Wilson et al., 2018). Here, we first calculate OC density from concurrent measurements of OC content and sediment dry bulk densities or porosities. This has two advantages: First, there is no need to transform the response variable as would be necessary in the case of OC content reported as weight percent or fractions. Second, only one model instead of two needs to be fitted. This is advantageous as fitting two models would likely increase the uncertainty of the predictions. Initially, a wide range of data sources were accessed. Ultimately, 373 samples fulfilled the criterion of providing OC content and dry bulk density/porosity measured on the same sample. These samples were collected and measured by the Geological Survey of Norway, the Centre for Environment, Fisheries and Aquaculture Science, Bakker and Helder (1993), and de Haas et al. (1997).

OC density $\rho_{\mathrm{OC}}\left(\mathrm{kg} \mathrm{m}^{-3}\right)$ was calculated from data on OC content $G\left(\mathrm{~g} \mathrm{~kg}^{-1}\right)$ and dry bulk density $\rho_{\mathrm{d}}\left(\mathrm{kg} \mathrm{m}^{-3}\right)$ :

$\rho_{\mathrm{OC}}=G \cdot \rho_{\mathrm{d}}$.

If not measured, dry bulk density was calculated from porosity $\phi$ and the grain density $\rho_{\mathrm{s}}\left(2650 \mathrm{~kg} \mathrm{~m}^{-3}\right)$ according to

$\rho_{\mathrm{d}}=(1-\varphi) \rho_{\mathrm{s}}$.

In the majority of cases $(52.8 \%)$, the OC concentrations referred to the $0-10 \mathrm{~cm}$ depth interval, but other depth intervals were also present; most frequently $0-1 \mathrm{~cm}(17.7 \%), 0-5 \mathrm{~cm}$ $(16.4 \%), 0-0.5 \mathrm{~cm}(6.7 \%)$, and $0-2 \mathrm{~cm}(4.6 \%)$. It was assumed that the reported values were representative of the upper $10 \mathrm{~cm}$ of the sediment column. The full dataset used for subsequent modelling is shown in Fig. 2 and provided as Table S2.

\subsection{Predictor variables}

The initial selection of environmental predictor variables was based on availability and expected relevance to OC. At this initial stage of conceptual model building (Guisan and Zimmermann, 2000), it might be prudent to include a wide range of potentially relevant variables. A selection of variables that are actually relevant for the model will be performed subsequently. A previous modelling study highlighted mud content in surficial sediments, bottom water temperature, and distance to the closest shoreline as important predictors for OC (Diesing et al., 2017). Other environmental controls on OC accumulation that have been inferred are sedimentation rate (Müller and Suess, 1979), bottom water oxygen concentration (Paropkari et al., 1992), and oxygen exposure time (Hartnett et al., 1998). There is less information available on relevant predictors for sedimentation rate, but it is assumed that sedimentation is favoured in deep basins with low current speeds and wave orbital velocities. Fine-grained sediments prevail in these environments and might be indicative for areas of sediment accumulation.

Some predictor variables were derived from other data layers: the geomorphology layer was derived from Harris et al. (2014) and contained the geomorphic features shelf, shelf valley, and glacial trough. The sedimentary environment was inferred from modelled Folk classes (Mitchell et al., 2019a). Initially, areas covered with mud, sandy mud, and muddy sand were assumed to be potentially accumulative. Boundaries were subsequently cleaned in ArcGIS to simplify the regions. These potential accumulation areas were critically reviewed in the light of measured sedimentation rates and geological interpretations of sediment cores (de Haas et al., 1997, and references therein). The remaining main areas of net deposition are shown in Fig. 1. The process is shown in Fig. A1 in Appendix A. Oxygen penetration depth was derived by applying relationships between measured oxygen penetration depth and mud content (John Barry, personal communication, 2018, Cefas) to the mud layer (Mitchell et al., 2019a). Oxygen exposure time was derived by dividing oxygen penetration depth by the modelled linear sedimentation rate (Hartnett et al., 1998).

All datasets were projected to Lambert azimuthal equalarea projection with a resolution of $500 \mathrm{~m}$. The full list of predictor variables is detailed in Table 1.

\section{Methods}

\subsection{Framework for spatial prediction and uncertainty estimation}

The same modelling framework was used for predicting sedimentation rates and OC densities. It is based on the quantile regression forest (QRF) algorithm (Meinshausen, 2006) to make spatial predictions of the response variables and to 
Table 1. Predictor variables used in the sedimentation rate and OC density models.

\begin{tabular}{|c|c|c|c|}
\hline $\begin{array}{l}\text { Predictor variable } \\
\text { (abbreviation) }\end{array}$ & Unit & Model & Source \\
\hline Bathymetry (Bathy) & $\mathrm{m}$ & Both & $\begin{array}{l}\text { EMODnet Bathymetry Consortium (2018), } \\
\text { Mitchell et al. (2019a) }\end{array}$ \\
\hline Euclidean distance to shoreline (DistCoast) & $\mathrm{m}$ & Both & Calculated \\
\hline Mud content (Mud) & $\%$ & Both & Mitchell et al. (2019a, b) \\
\hline Sand content (Sand) & $\%$ & $\begin{array}{l}\text { Sedimentation } \\
\text { rate }\end{array}$ & Mitchell et al. (2019a, b) \\
\hline Gravel content (Gravel) & $\%$ & $\begin{array}{l}\text { Sedimentation } \\
\text { rate }\end{array}$ & Mitchell et al. (2019a, b) \\
\hline Folk textural class (Folk) & - & $\begin{array}{l}\text { Sedimentation } \\
\text { rate }\end{array}$ & Mitchell et al. (2019a, b) \\
\hline $\begin{array}{l}\text { Summer suspended particulate matter } \\
\text { (SPM_summer) }\end{array}$ & $\mathrm{g} \mathrm{m}^{-3}$ & Both & Mitchell et al. (2019a, c) \\
\hline $\begin{array}{l}\text { Winter suspended particulate matter } \\
\text { (SPM_winter) }\end{array}$ & $\mathrm{g} \mathrm{m}^{-3}$ & Both & Mitchell et al. (2019a, c) \\
\hline M2 tidal current speed (M2Speed) & $\mathrm{ms}^{-1}$ & Both & Mitchell et al. (2019a, c) \\
\hline Peak orbital velocity (PkOrbVel) & $\mathrm{ms}^{-1}$ & Both & Mitchell et al. (2019a, c) \\
\hline $\begin{array}{l}\text { Ratio of tidal boundary layer thickness to water } \\
\text { depth (delta_star) }\end{array}$ & - & $\begin{array}{l}\text { Sedimentation } \\
\text { rate }\end{array}$ & Williams et al. (2019) \\
\hline Geomorphology (Geomorph) & - & $\begin{array}{l}\text { Sedimentation } \\
\text { rate }\end{array}$ & Derived from Harris et al. (2014) \\
\hline Sedimentary environment (SedEnv) & - & $\begin{array}{l}\text { Sedimentation } \\
\text { rate }\end{array}$ & Derived from Mitchell et al. (2019a) \\
\hline Mean bottom water oxygen (O2_mean) & $\mathrm{mol} \mathrm{m}^{-3}$ & OC density & $\begin{array}{l}\text { http://www.bio-oracle.org/index.php (last access: } \\
17 \text { January 2019), Assis et al. (2018), Tyberghein et } \\
\text { al. (2012) }\end{array}$ \\
\hline Oxygen penetration depth (OPD) $\delta$ & $\mathrm{cm}$ & OC density & $\begin{array}{l}\text { Calculated from mud content } \\
\text { (John Barry, personal communication, } 2018 \text {, } \\
\text { Cefas): } \\
\delta=e^{(1.0745-0.1431 \cdot \mathrm{mud})} \text { for mud } \leq 8.0 \% \\
\delta=e^{-0.0706} \text { for mud }>8.0 \%\end{array}$ \\
\hline Oxygen exposure time (OET) & years & OC density & $\begin{array}{l}\text { Calculated from sedimentation rate and oxygen } \\
\text { penetration depth: } \\
\text { OET }=\frac{\delta}{\omega}\end{array}$ \\
\hline Mean bottom water temperature (Temp_mean) & ${ }^{\circ} \mathrm{C}$ & OC density & $\begin{array}{l}\text { http://www.bio-oracle.org/index.php } \\
\text { Assis et al. (2018), Tyberghein et al. (2012) }\end{array}$ \\
\hline $\begin{array}{l}\text { Mean sea surface primary production } \\
\text { (SurfPP_mean) }\end{array}$ & $\mathrm{g} \mathrm{m}^{-3} \mathrm{~d}^{-1}$ & OC density & $\begin{array}{l}\text { http://www.bio-oracle.org/index.php } \\
\text { Assis et al. (2018), Tyberghein et al. (2012) }\end{array}$ \\
\hline Sedimentation rate (SedRate) & $\mathrm{cm} \mathrm{yr}^{-1}$ & OC density & Modelled (this study) \\
\hline
\end{tabular}


(a) Linear Sedimentation Rate $\left({\left.\mathrm{cm} \mathrm{yr}^{-1}\right)}^{-1}\right.$

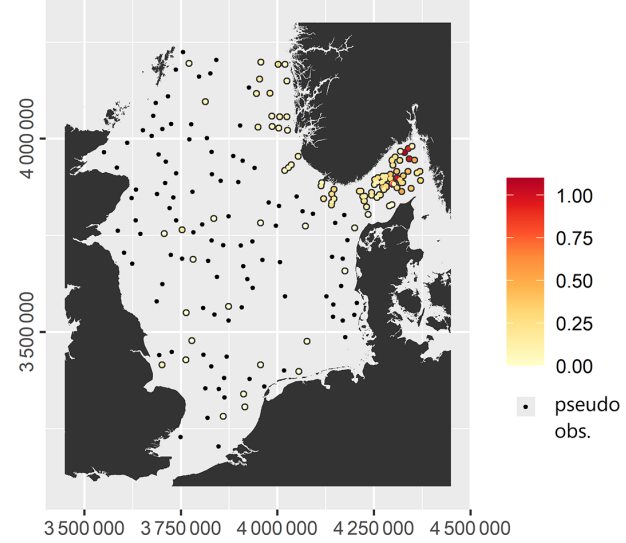

(b) Organic Carbon Density $\left(\mathrm{kg} \mathrm{m}^{-3}\right)$

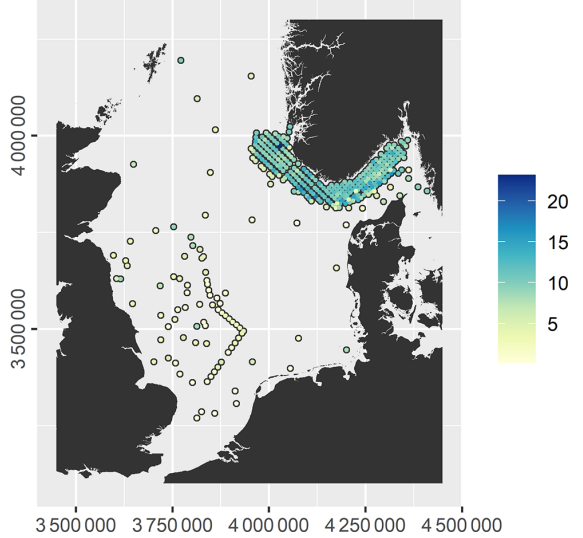

Figure 2. Available samples on sedimentation rate (a) and OC density (b).

estimate the uncertainty in the predictions in a spatially explicit way. QRF is a generalisation of the random forest algorithm (Breiman, 2001), which aggregates the conditional mean from each tree in a forest to make an ensemble prediction. QRF also returns the whole conditional distribution of the response variable. This allows us to determine the underlying variability of an estimate by means of prediction intervals or the standard deviation.

Prediction uncertainty may be divided into four main components: uncertainty in the response data, in the predictor variables, in the model, and in variations of available data (Guevara et al., 2018). It was not possible to address uncertainty related to the first two components, as information on measurement error of the response variables or uncertainty associated with the predictor variables was not available. However, the modelling framework addresses uncertainty in the model by calculating the standard deviation of the QRF predictions. Furthermore, the sensitivity of the model to variations in the available data was estimated by means of resampling. To that end, the response data were repeatedly (25 times in this case) split into training and test subsets at a ratio of $7: 3$, and 25 models were subsequently built based on these splits. This resampling scheme is known as Monte Carlo cross-validation. The sensitivity is derived by calculating the standard deviation of the 25 predictions for every pixel. The total uncertainty is the sum of the model uncertainty and the sensitivity. The methodology was adapted from Guevara et al. (2018).

Prior to model building, the predictor variables were submitted to a variable selection process. This was achieved via the Boruta variable selection wrapper algorithm (Kursa and Rudnicki, 2010), which identified important predictor variables. Random forest has been shown to perform well without parameter tuning. Our own experience shows that the gains made by random forest model tuning are comparatively small, while at the same time this step might be time consuming, especially when tuning an array of parameters. As
QRF is based on random forest, we assume that the same holds true here. Only limited model tuning was therefore carried out. The number of variables to consider at any given split $\left(m_{\text {try }}\right)$ was tuned in a grid search using a 10-fold crossvalidation scheme with three repeats on the training dataset. It is usually sufficient to set the number of trees in the forest $\left(n_{\text {tree }}\right)$ to a high value; 500 was selected in this case.

The QRF algorithm provides a means of ranking predictor variables by their importance to prediction accuracy. Variable importance is measured as the mean increase in node purity. Node purity represents how well the trees in the forest split the data.

The model performance was assessed based on the test data of 25 resampling iterations. The root mean square error (RMSE) was calculated according to

$\operatorname{RMSE}=\sqrt{\frac{1}{n} \cdot \sum_{i=1}^{n}\left(y_{i}-\hat{y}_{i}\right)^{2}}$,

whereby $n$ denotes the number of observations, $y_{i}$ represents observed values and $\hat{y}_{i}$ represents predicted values. RMSE measures how far apart on average predicted values are from observed values. It might range from 0 to infinity, with an ideal value of 0 . It is reported in the same units as the predicted quantity. Additionally, the explained variance $\left(r^{2}\right)$ was calculated from the observed and predicted values.

The analysis was carried out in R 3.6.1 statistical software (R Core Team, 2018) and RStudio 1.2.1335. The full workflows are documented as R Notebook files (Files S1 and S2 in the Supplement).

\subsection{Calculation of OC stocks}

The OC stock $\left(m_{\mathrm{OC}}\right)$ of surface sediments in the North Sea and Skagerrak was calculated by summing the predicted OC densities of all pixels and multiplying with the reference 
depth $(d=0.1 \mathrm{~m})$ and the area of a pixel $\left(A=250000 \mathrm{~m}^{2}\right)$ :

$m_{\mathrm{OC}}=d \cdot A \cdot \sum \rho_{\mathrm{OC}}$

The total uncertainty of the predicted OC stock was calculated in the same way. OC stocks and uncertainties are reported in teragrams of carbon $(\mathrm{TgC})$, where $1 \mathrm{TgC}$ equals $1 \mathrm{Mt} \mathrm{C}$ or $0.083 \mathrm{Tmol} \mathrm{C}$.

\subsection{Calculation of $\mathrm{OC}$ accumulation rates}

OC accumulation rates (OCARs in $\mathrm{g} \mathrm{m}^{-2} \mathrm{yr}^{-1}$ ) were calculated by multiplying predicted OC densities with predicted sedimentation rates:

$\operatorname{OCAR}=\rho_{\mathrm{OC}} \cdot \omega$

Uncertainties were propagated by taking the square root of the sum of squared relative uncertainties:

$$
\frac{\delta \mathrm{OCAR}}{\mathrm{OCAR}}=\sqrt{\left(\frac{\delta \rho_{\mathrm{OC}}}{\rho_{\mathrm{OC}}}\right)^{2}+\left(\frac{\delta \omega}{\omega}\right)^{2}},
$$

whereby $\delta$ denotes the uncertainty of a quantity. The full workflow is documented as an R Notebook file (File S3).

\subsection{Regionalisation}

An unsupervised classification was carried out to provide a regionalisation of the North Sea environment with regard to processing of $\mathrm{OC}$ at the seafloor. The following environmental variables were selected: bathymetry, tidal current speed, peak orbital velocity, oxygen penetration depth, OC density, and OC accumulation rate. These are expected to have a strong impact on OC processing. A $k$-means clustering was conducted utilising the algorithm of Hartigan and Wong (1979). Prior to clustering, the input variables were normalised, and a principal component analysis was carried out to limit co-linearity in the input data. The first four principal components, accounting for $95.5 \%$ of the variance, were selected for further analysis. The selection of the number of clusters to be requested was based on an elbow plot, which resulted in three clusters. The full workflow is documented as an R Notebook file (File S4).

\section{Results}

\subsection{Sedimentation rates}

Of the 13 predictor variables initially selected for model building (Table 1), only the Folk textural class was found unimportant and hence removed. The five most important predictor variables were the M2 tidal current velocity, the ratio of tidal boundary layer thickness to water depth, the peak orbital velocity, sand content, and mud content (Fig. 3). The selected predictors are shown in Fig. A2.
The model had an RMSE of $0.13 \pm 0.03 \mathrm{~cm} \mathrm{yr}^{-1}$ and an $r^{2}$ of $0.58 \pm 0.09$. Predicted sedimentation rates range from 0 to $0.61 \mathrm{~cm} \mathrm{yr}^{-1}$, while the total uncertainty varies between 0.12 and $0.53 \mathrm{~cm} \mathrm{yr}^{-1}$ (Fig. 4). Sedimentation rates are highest in the Norwegian Trough. Zero net sedimentation occurs in large parts of the North Sea, with slightly elevated sedimentation rates linked to shallow basins such as the inner German Bight, the Elbe palaeo-valley, the Oyster Ground, the Outer Silver Pit, and Devil's Hole. The patterns of prediction uncertainty follow those of the sedimentation rate.

\subsection{Organic carbon density}

All 13 predictor variables initially selected for model building (Table 1) were deemed important. The five most important predictor variables were bathymetry, sedimentation rate, bottom water temperature, oxygen exposure time, and mud content (Fig. 3). The selected predictors are shown in Fig. A3.

The model had an RMSE of $2.16 \pm 0.25 \mathrm{~kg} \mathrm{~m}^{-3}$ and an $r^{2}$ of $0.72 \pm 0.06$. Predicted OC densities range from 1.11 to $13.59 \mathrm{~kg} \mathrm{~m}^{-3}$, while the total uncertainty varies between 0.89 and $8.07 \mathrm{~kg} \mathrm{~m}^{-3}$ (Fig. 5). OC densities are highest in the Norwegian Trough. Intermediate OC densities are found in the northern North Sea and shallow basins, while they are lowest on Dogger Bank, in the Southern Bight, and along the Danish coast. Note that uncertainties in parts of the Norwegian Trough are comparatively low due to a high sampling density (Fig. 2).

The OC stock of surface sediments of the North Sea and Skagerrak amounts to $230.5 \pm 134.5 \mathrm{TgC}$, of which $60.1 \pm 18.3 \mathrm{TgC}$ is stored in the Norwegian Trough. This means that $25.9 \%$ of the total OC stock is located within the Norwegian Trough, which accounts for $11 \%$ of the surface area.

\subsection{Organic carbon accumulation rates}

OCARs vary between 0.02 and $66.18 \mathrm{~g} \mathrm{~m}^{-2} \mathrm{yr}^{-1}$, while the total uncertainty ranges from 0.20 to $57.90 \mathrm{~g} \mathrm{~m}^{-2} \mathrm{yr}^{-1}$ (Fig. 6). OC accumulation rates are effectively zero over large parts of the North Sea. Marked accumulation of OC is restricted to the Norwegian Trough, which accumulates $1.24 \pm 1.30 \mathrm{Tg} \mathrm{C} \mathrm{yr}^{-1}$. This accounts for nearly $87 \%$ of the total OC accumulation of $1.43 \pm 2.07 \mathrm{Tg} \mathrm{C} \mathrm{yr}^{-1}$ in the North Sea and Skagerrak.

\subsection{Regionalisation}

The unsupervised classification resulted in regions that were distinct regarding bathymetry, hydrodynamics, oxygen penetration, and OC (Fig. 7). Region 2 (green) is characterised by shallow water, strong hydrodynamics, deep oxygen penetration, low OC densities, and OC accumulation close to zero. Region 3 (dark blue) is characterised by deep water, weak hydrodynamics, shallow oxygen penetration, high OC 
(a) Sedimentation rate

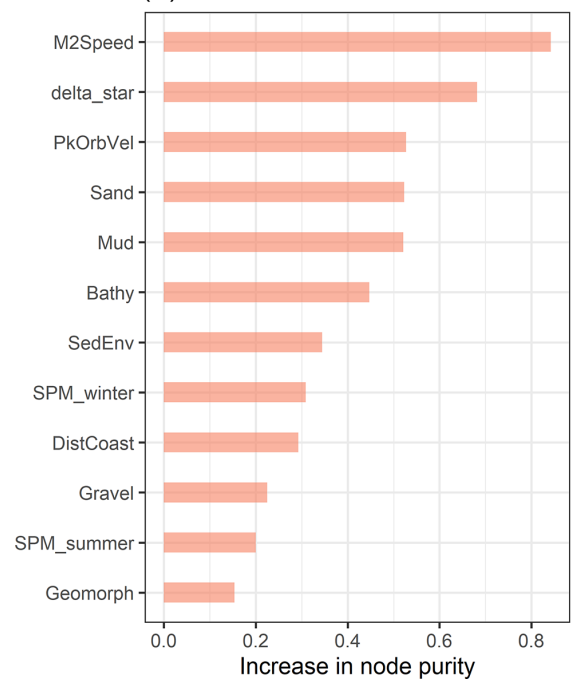

(b) Organic carbon density

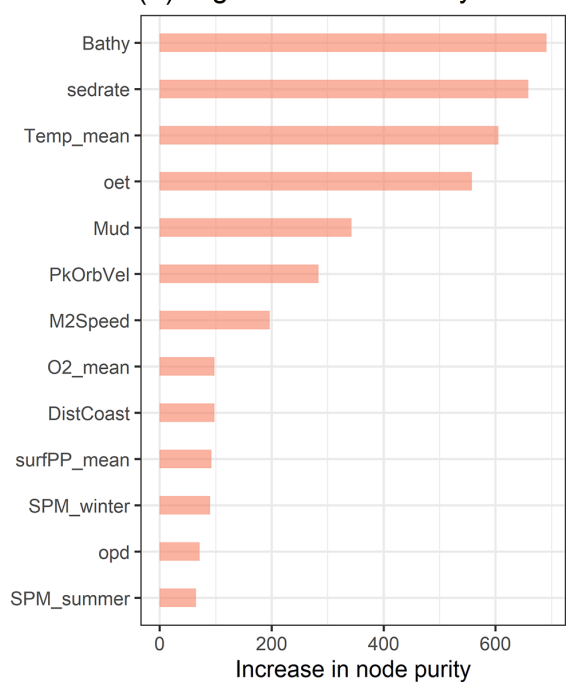

Figure 3. Selected predictor variables and relative variable importance of the sedimentation rate (a) and organic carbon density (b) models.

(a) Sedimentation Rate $\left(\mathrm{cm} \mathrm{yr}^{-1}\right)$

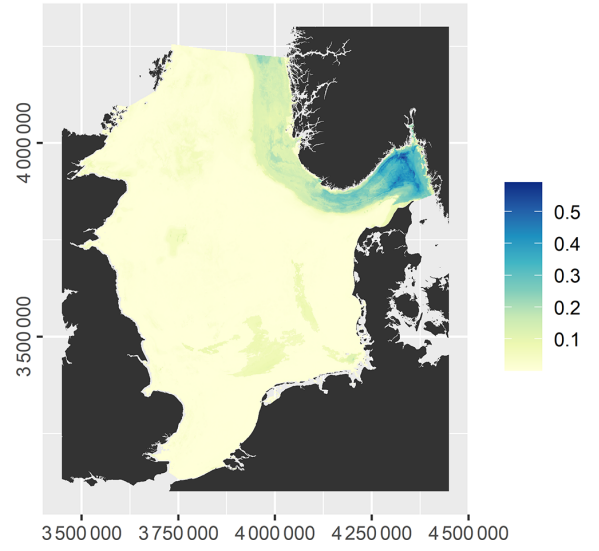

(b) Total Uncertainty $\left(\mathrm{cm} \mathrm{yr}^{-1}\right)$

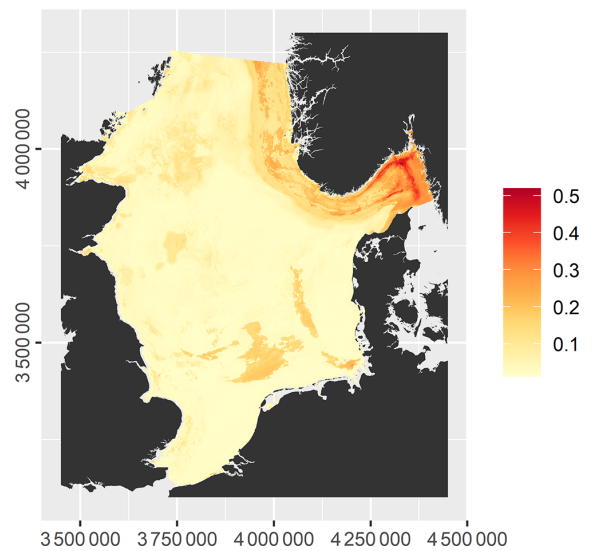

Figure 4. Predicted sedimentation rate (a) and associated uncertainty in the predictions (b).

densities, and high OC accumulation. Region 1 (light blue) has characteristics that lie intermediate between those of regions 2 and 3.

\section{Discussion}

We have presented estimates of OC stocks and accumulation rates and their associated spatially explicit uncertainties that were derived with the same modelling framework. Our results show that a substantial amount of OC, $231 \mathrm{Tg} \mathrm{C}$ within the upper $0.1 \mathrm{~m}$ of seabed sediment, is stored in surface sediments of the North Sea and Skagerrak. OC accumulation is effectively restricted to the Norwegian Trough, which accumulates $1.2 \mathrm{TgC}$ annually. In the following we discuss the relevance of our results by comparing them with other estimates of OC stored in shelf sea sediments, coastal vegetated habitats, and terrestrial soils, which have been highlighted as significant OC stores. We further discuss zones of OC processing at the seafloor based on our regionalisation, with potential implications for marine management and suggestions for future research.

\subsection{Relevance}

The surface sediments of the North Sea and Skagerrak store $230.5 \pm 134.5 \mathrm{Tg}$ of OC. This compares with 9.6 to $25.0 \mathrm{Pg} \mathrm{C}$ stored globally in bioturbated Holocene shelf sediments (0$10 \mathrm{~cm}$ ) as estimated by LaRowe et al. (2020). Hence, sediments in the North Sea and Skagerrak store approximately $0.9 \%-2.4 \%$ of the global stock in an area that accounts for $\approx 1.7 \%$ of the global continental shelf.

When comparing uncertainties in OC stock estimates with other reported values of spatial predictions at a re- 
(a) OC Density $\left(\mathrm{kg} \mathrm{m}^{-3}\right)$

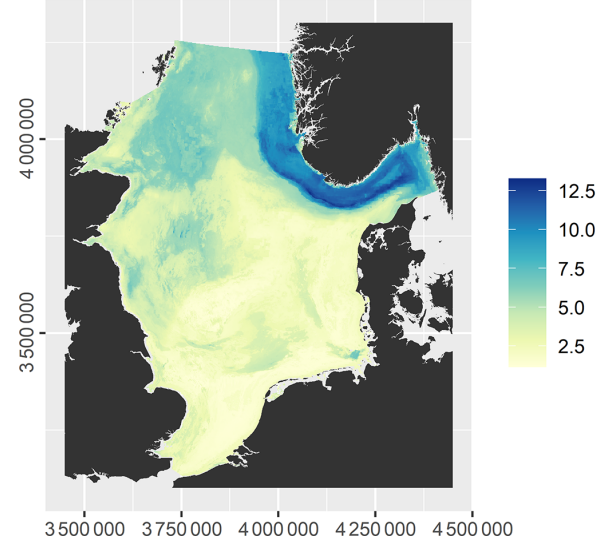

(b) Total Uncertainty $\left(\mathrm{kg} \mathrm{m}^{-3}\right)$

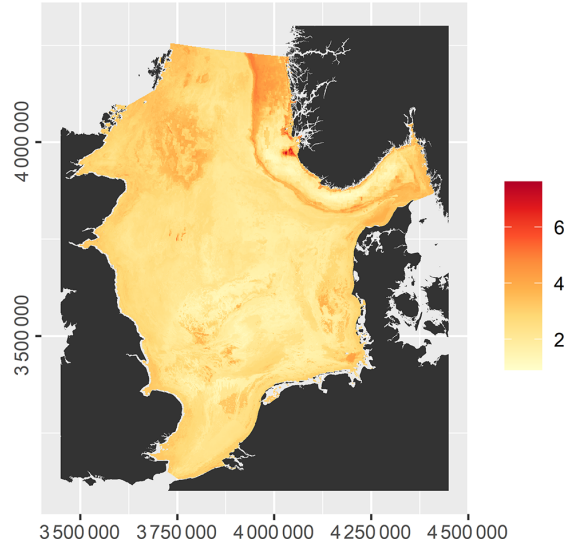

Figure 5. Predicted OC density (a) and associated uncertainty in the predictions (b).

(a) OC Accumulation Rate $\left(\mathrm{g} \mathrm{m}^{-2} \mathrm{yr}^{-1}\right)$

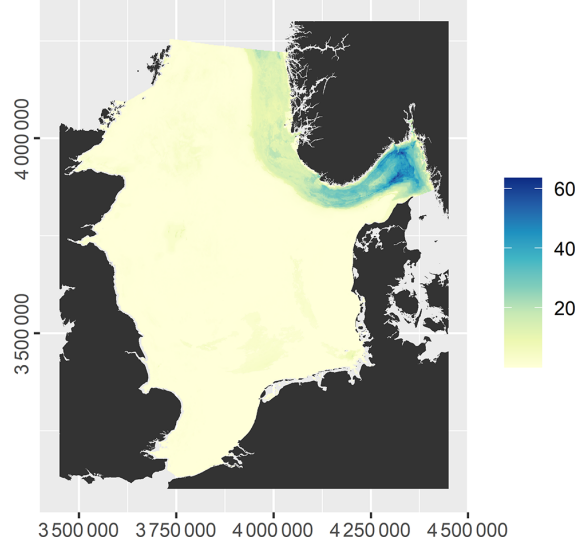

(b) Total Uncertainty $\left(\mathrm{g} \mathrm{m}^{-2} \mathrm{yr}^{-1}\right)$

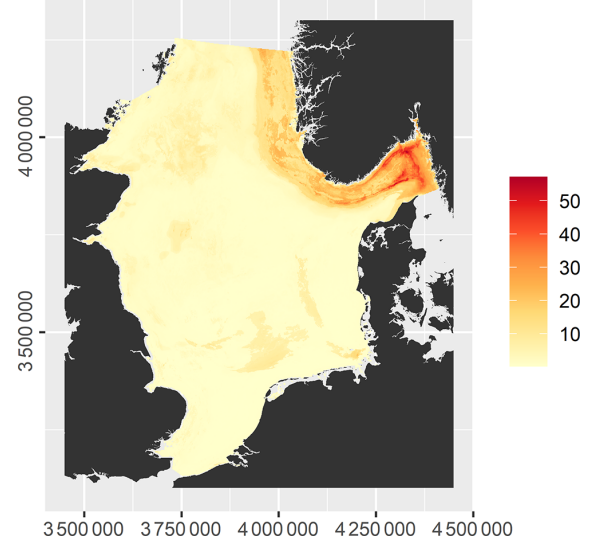

Figure 6. Calculated OC accumulation rate (a) and associated uncertainty (b).

gional to global scale, we find that our value of $58 \%$ (100. 134.5 Tg C/230.5 Tg C) is similar to that reported by Lee et al. (2019), amounting to $49 \%$, while other studies did not report any estimates of uncertainty (Diesing et al., 2017; LaRowe et al., 2020). Lower uncertainties have been reported from local studies (e.g. Hunt et al., 2020), presumably due to a tighter coupling between response and predictor variable. An intrinsic assumption of modelling approaches such as the one presented here is that the measured response variable is representative at the scale of the pixel size of predictor variables. The likelihood for this being true increases when the pixel size approaches the size of the seabed area that was sampled with a grab or corer. Higher-resolution predictor variables, as frequently used in local studies, might therefore have lower uncertainties associated with the predictions. It should also be considered that the ways in which uncertainty is estimated and reported vary, thereby limiting the scope of such comparisons. We believe that our approach to uncertainty assessment is very robust as it estimates uncertainty in the model and in variations of available data.

Previous estimates of OC stocks in the upper $10 \mathrm{~cm}$ of the sediment column of the north-west European continental shelf amount to 230-882 Tg C (Diesing et al., 2017). The estimated stock of $230.5 \pm 134.5 \mathrm{Tg} \mathrm{C}$ contained in the upper $10 \mathrm{~cm}$ of the sediments of the North Sea and Skagerrak, which account for approximately $50 \%$ of the area of the north-west European continental shelf, falls well within this estimate. Of this stock, approximately $60 \mathrm{Tg} \mathrm{C}$ or $26 \%$ is stored within the Norwegian Trough, indicating the importance of this glacial feature as a store of OC.

To gauge the importance of North Sea shelf sediments as an OC store, we compare them with coastal habitats and terrestrial soils as follows: coastal vegetated habitats (salt marsh, seagrass, kelp, and tidal flat) are known to bury large amounts of carbon despite occupying only $0.2 \%$ of the global ocean surface (Duarte et al., 2005, 2013). Coastal habitats on the north-west European continental shelf store 

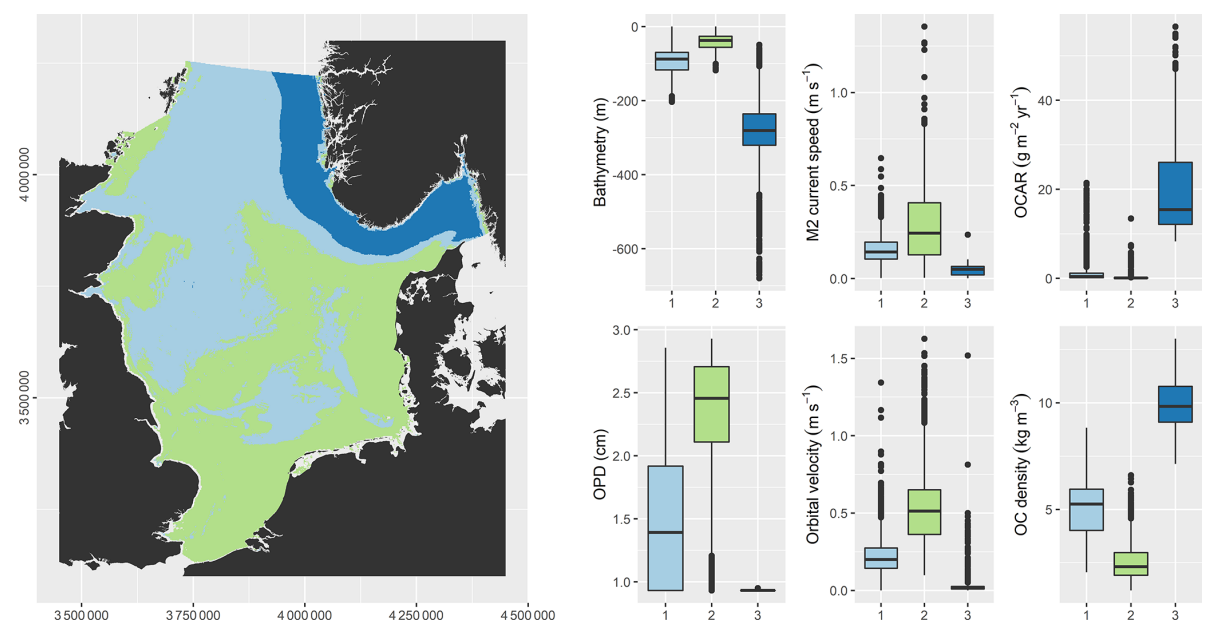

Figure 7. Regionalisation of the North Sea and Skagerrak: region 1 (light blue) - transition zone; region 2 (green) - turnover zone; and region 3 (dark blue) - burial zone. Note that boxplots are based on 10000 randomly placed points rather than all pixels.

between 8.3 and $40.8 \mathrm{TgC}$ in the upper $10 \mathrm{~cm}$ in an area of 20900-35000 km² (Legge et al., 2020), equating to OC densities between 24 and $195 \mathrm{~kg} \mathrm{~m}^{-3}$. This indicates that shelf sediment stocks (230.5 Tg C) are approximately an order of magnitude larger despite lower OC densities of 1.1 to $13.6 \mathrm{~kg} \mathrm{~m}^{-3}$.

Soils are the largest carbon store on land; globally they are estimated to hold $1325 \mathrm{Pg} \mathrm{C}$ in the upper $1 \mathrm{~m}$ (Köchy et al., 2015). Topsoil $(0-10 \mathrm{~cm})$ OC stocks based on SoilGrids250m (Hengl et al., 2017) of the countries bordering on the North Sea and Skagerrak are shown in Table 2. Note that topsoil OC stocks refer to the entire area of the respective country, while marine OC stocks refer to the proportion of the Exclusive Economic Zone (EEZ) that falls within our study area. While marine sediment OC stocks are generally lower than their soil counterparts, marine stocks are not negligible in several countries. These additional OC stocks amount to $7.5 \%, 7.1 \%$, and $6.6 \%$ of topsoil stocks in Denmark, the Netherlands, and the United Kingdom, respectively. Furthermore, some countries have EEZs considerably larger than their share of the North Sea and Skagerrak considered here. Hence, there is potential for an even larger marine OC stock.

The accumulation of OC is effectively limited to the Norwegian Trough, with the highest rates found in the Skagerrak. Predicted OCARs vary between approximately 4 and $66 \mathrm{~g} \mathrm{~m}^{-2} \mathrm{yr}^{-1}$ in the Norwegian Trough, with a mean OCAR of $19.4 \mathrm{~g} \mathrm{~m}^{-2} \mathrm{yr}^{-1}$. Reported OCARs measured in fjord sediments in Norway and Sweden bordering on the North Sea range from 12 to $54 \mathrm{~g} \mathrm{~m}^{-2} \mathrm{yr}^{-1}$ (Huguet et al., 2007; Müller, 2001; Nordberg et al., 2001, 2009; Skei, 1983; Smittenberg et al., 2004, 2005; Velinsky and Fogel, 1999), indicating that OCARs in the Norwegian Trough are of a comparable magnitude. However, fjords in Scotland and Ireland have been shown to be heterogeneous in sediment distribution and OC concentrations (Smeaton and Austin, 2019) and hence also OC accumulation. Judging from published sediment maps (e.g. Elvenes et al., 2019), the same applies to fjords in Norway. Conversely, the Norwegian Trough is characterised by fine-grained sediments (Mitchell et al., 2019a), and OC accumulation occurs throughout the geomorphological structure. Additionally, the area of the Norwegian Trough is much larger than even the largest fjords in Norway, highlighting its relevance as the most important place of OC accumulation in the North Sea and Skagerrak.

Collectively, the sediments of the Norwegian Trough accumulate $1.24 \mathrm{Tg} \mathrm{Cyr}^{-1}$ over an area of approximately $62000 \mathrm{~km}^{2}$, but the uncertainty in this estimate is on the same order of magnitude as the estimate. Nevertheless, this estimate is in good agreement with an earlier published value of $1 \mathrm{TgC} \mathrm{yr}^{-1}$ (de Haas and van Weering, 1997). For comparison, $3.53 \pm 2.90 \mathrm{Tg} \mathrm{C} \mathrm{yr}^{-1}$ is accumulated in the muddy basins of the Baltic Sea (area: $164800 \mathrm{~km}^{2}$ ) (Leipe et al., 2011). Coastal habitats (salt marsh, seagrass, kelp, and tidal flat) on the north-west European continental shelf have been estimated to accumulate $0.2-0.7 \mathrm{Tg} \mathrm{Cyr}^{-1}$ (Legge et al., 2020).

\subsection{Zones of organic carbon processing at the seafloor}

The regionalisation based on selected characteristic parameters pertaining to OC accumulation and storage (Fig. 7) has shown that the North Sea and Skagerrak can be divided into distinct zones. The results indicate that shelf sediments can act in distinctly different ways in the context of OC processing at the seafloor. In a way, they also reflect the scientific discourse over the last half century or so: initially, process studies on OC cycling on the continental shelf (e.g. Balzer, 1984; Jørgensen, 1977; Martens and Val Klump, 1984) focussed on fine-grained sediments associated with hydrodynamically quiet environments, relatively constant sediment accumula- 
Table 2. Breakdown of topsoil $(0-10 \mathrm{~cm})$ OC stocks by country (Hengl et al., 2017) compared with marine sediment OC stocks. Topsoil OC stocks refer to the entire area of the respective country bordering on the North Sea and Skagerrak, while marine OC stocks refer to the proportion of the EEZ that falls within our study area.

\begin{tabular}{lrrrr}
\hline Country & $\begin{array}{r}\text { Soil OC } \\
(0-10 \mathrm{~cm}), \mathrm{TgC}\end{array}$ & $\begin{array}{r}\text { Marine sediment OC } \\
(0-10 \mathrm{~cm}), \mathrm{Tg} \mathrm{C}\end{array}$ & $\begin{array}{r}\text { Marine sediment OC, } \\
\text { \% of soil OC }\end{array}$ & $\begin{array}{r}\text { Mapped area, } \\
\text { \% of total EEZ }\end{array}$ \\
\hline Belgium & 109.3 & 0.7 & 0.7 & 95.3 \\
Denmark & 236.6 & 17.8 & 7.5 & 55.1 \\
France & 2026.1 & 0.4 & 0.0 & 0.5 \\
Germany & 1808.9 & 8.8 & 0.5 & 64.4 \\
the Netherlands & 198.0 & 14.1 & 7.1 & 91.5 \\
Norway & 2253.6 & 83.9 & 3.7 & 13.7 \\
Sweden & 3333.2 & 5.0 & 0.1 & 3.7 \\
United Kingdom & 1572.3 & 103.1 & 6.6 & 32.7 \\
\hline
\end{tabular}

tion, and diffusion-dominated porewater transport. This has led to the notion of rapidly accumulating coastal sediments associated with high sedimentation, high $\mathrm{OC}$ burial rates, and low oxygen penetration depths (Aller, 2014; Canfield, 1994; Middelburg, 2019; Middelburg et al., 1997).

However, approximately $50 \%$ (Hall, 2002) to $70 \%$ (Emery, 1968) of the global continental shelf consists of coarse-grained sediments (gravel and sand) with high permeabilities. Unidirectional and wave orbital water flows interacting with microscale topography (e.g. ripples and biogenic mounds) at the water-sediment interface lead to increased fluid exchange rates compared to exchange by molecular diffusion (Huettel et al., 1996; Precht and Huettel, 2003). Interaction of flows with surface microtopography increases oxygen penetration depths (Huettel and Rusch, 2000). As a consequence of advective porewater flows, permeable sediments may act as biocatalytic filters, notable for their high reaction rates, intense recycling, and extreme spatial and temporal dynamics of biogeochemical processes (Huettel et al., 2003, 2014).

The seafloor in the Southern Bight, Dogger Bank, and Fisher Bank, as well as in the proximity of west-facing coastlines (apart from the Norwegian west coast), is characterised by shallow water depths, high tidal current speeds, and high wave orbital velocities. The probability that the seabed gets disturbed by waves and currents to a depth of $3 \mathrm{~cm}$ at least once a year is above $50 \%$ in these areas (Aldridge et al., 2015: Fig. 17a). It can therefore be assumed that ripples are present in these areas at least temporarily and that the interaction of unidirectional and oscillatory currents with these roughness elements leads to enhanced fluid exchange, as sediments are sufficiently permeable. The advective supply of oxygen to the sedimentary microbial community facilitates the effective degradation of OC (Huettel et al., 2014). Consequently, oxygen penetrates deep into these sediments and OC density is low. The potential for longer-term accumulation of OC is very low, as these environments are characterised by repeated erosion-redeposition cycles. This zone of rapid OC processing might equate to the turnover zone of Huettel and Rusch (2000).

Conversely, the seabed of the Norwegian Trough is characterised by water depths in excess of $200 \mathrm{~m}$ and experiences very subdued wave and current agitation. Fluid transport in the sediment is therefore driven by molecular diffusion, mediated by bioturbation. Bioturbation contributes to a balance in the sedimentary OC budget by transporting labile OC to deeper horizons where degradation efficiency is lower (Zhang et al., 2019). The lack of advective oxidation (Huettel et al., 2014; Huettel and Rusch, 2000) translates into slower OC degradation. Fine-grained sediments provide mineral protection (Hedges and Keil, 1995; Hemingway et al., 2019; Keil and Hedges, 1993; Mayer, 1994), which also promotes OC preservation. Short oxygen exposure times (Hartnett et al., 1998) due to shallow oxygen penetration depths and relatively high sedimentation rates limit the time for aerobic mineralisation. Collectively, this leads to high OC densities and accumulation rates. This zone might be termed a burial zone according to Huettel and Rusch (2000). However, for consistency with our analysis we term this zone an accumulation zone.

De Haas and van Weering (1997) estimated that only $10 \%$ of the OC deposited in the Norwegian Trough is derived from local primary production and that the remainder originates from other sources. A large part of this allochthonous OC is transported into the Norwegian Trough along the Dutch, German, and Danish coasts by an anticlockwise residual circulation (de Haas et al., 2002). This transport is thought to be intermittent, with the rate of transport dependent on the strength of wind-induced waves and currents (de Haas and van Weering, 1997). The OC being deposited in the Norwegian Trough is mostly refractory, as it has undergone several erosion-transport-deposition cycles prior to final deposition (de Haas et al., 2002).

A third zone is situated in the northern North Sea and the shallow depositional areas of the southern North Sea. It has a transitional character with water depths, current speeds, wave orbital velocities, and oxygen penetration depths intermedi- 
ate between those of the turnover and the burial zones. OC densities are also intermediate, while $\mathrm{OC}$ accumulation is negligible in this transitional zone.

\subsection{Implications for management}

We have shown that seabed sediments of the North Sea and Skagerrak are an important store of OC. Furthermore, the Norwegian Trough is an important centre of OC accumulation, with rates comparable with neighbouring fjords. Based on those results it was possible to identify zones of rapid OC turnover and zones of $\mathrm{OC}$ accumulation. These zones have different roles in terms of OC processing and storage and hence will have different relevance in the context of managing OC stores at the seabed.

Marine sediment OC stocks are presently not considered in the context of national carbon inventories for greenhouse gas reporting. The question has been raised about whether those stocks should be considered part of national carbon accounting (Avelar et al., 2017). It is becoming clearer that marine sediments store sizeable amounts of OC (Diesing et al., 2017; Lee et al., 2019; Luisetti et al., 2019), which might be vulnerable to human activities such as demersal fishing (Paradis et al., 2020). Likewise, there exist hotspots of OC accumulation (Bianchi et al., 2018) like the Norwegian Trough, as demonstrated here. A further exploration as to how management of marine sediment OC could contribute towards national greenhouse gas emission reduction targets might therefore be prudent; however, this requires new accounting guidance and governance frameworks (Luisetti et al., 2020). The assessment of the OC stock size should be coupled with an assessment of the anthropogenic impacts on that stock (Avelar et al., 2017). When assessed in the context of naturally occurring disturbance (e.g. by currents and waves), this will contribute towards a more complete picture of the vulnerability of marine sediment OC stocks to remineralisation and potential release of $\mathrm{CO}_{2}$ to the atmosphere (Atwood et al., 2020). We provide spatially explicit information on stock sizes and the uncertainty in the estimates, which could be utilised in such vulnerability assessments.

While the importance of Blue Carbon ecosystems for OC drawdown has been highlighted in the past (Duarte et al., 2005; Mcleod et al., 2011; Nellemann et al., 2009), the annual rate of OC accumulation by coastal vegetated habitats (Legge et al., 2020) is less than that of seafloor sediments at a sea-basin scale. It might therefore be prudent to further explore the idea of MPAs as a tool to mitigate climate change by protecting and enhancing marine sedimentary OC stores (Roberts et al., 2017), especially as the climate mitigation potential of marine natural climate solutions (Griscom et al., 2017) has so far been overlooked.

Although more research is needed, it is becoming clearer now that seabed disturbance by demersal fishing leads to increased OC mineralisation in cohesive sediments in the short term (van de Velde et al., 2018) and a general impoverish- ment in OC in the long term (Martín et al., 2014a). Protecting regional hotspots of $\mathrm{OC}$ accumulation from fishinginduced disturbance might therefore be a suitable measure to increase the climate mitigation potential of the seabed. Likely sites that might benefit from protection are to be found in the accumulation zone (i.e. the Norwegian Trough), while it is unlikely that the turnover zone yields any potential areas worth protecting in this context. Our results could be used jointly with maps showing the footprint of demersal fishing (Eigaard et al., 2016) and other resources to identify potential sites for the establishment of "carbon protection zones". Such management measures that limit the impacted surface area, allowing carbon stocks and faunal communities in the sediment to recover from a disturbance and resulting in the recovery of carbon accumulation, might be preferable over technical modifications that reduce the penetration depth of fishing gear (De Borger et al., 2020). Recent research also highlights that temporal closures of fishing grounds might not be sufficient to restore the seafloor (Paradis et al., 2020). It must also be considered that the OC stocks, as mapped in this study, likely have been affected already by decades of demersal fishing. Our maps therefore do not represent a baseline in a sense of an undisturbed state.

Additionally, more research on the reactivity of $\mathrm{OC}$ is required to better understand the relationships between OC mineralisation and seabed disturbance. The mineralisation of predominantly refractory OC caused by demersal fishing might be limited or even negligible. In the Skagerrak, oxygen micro-profile measurements indicated that mineralisation rates were independent of OC content but related to the input of fresh OC by primary production (Bakker and Helder, 1993). This suggests that preferentially fresh labile OC was mineralised, while allochthonous OC that accounts for $90 \%$ of the OC in the Norwegian Trough (de Haas and van Weering, 1997) might be largely unreactive. Conversely, van de Velde et al. (2018) suggested that OC mineralisation is stimulated after sediment disturbance, likely due to the enhanced decomposition of previously buried refractory OC when it comes into contact with labile OC, a process known as priming (Steen et al., 2016). Another question of interest is to what extent a potential reduction in mineralisation rates due to areal protection of OC stocks might influence primary production and thus supply of $\mathrm{OC}$ to the seabed.

\subsection{Suggestions for future research}

We have utilised a modelling scheme that allowed us to estimate the uncertainty in the model and in variations of available data. However, this robust methodology led to relatively high uncertainties in the predictions. We assume that the most likely reason for this is the nature of the available sample datasets. As we utilised archived samples collected over many years by different organisations for various purposes, this has led to a somewhat heterogeneous dataset with biases regarding coverage of the temporal, geographical, and 
environmental (i.e. predictor variable) space. While we believe that making best use of existing data is important and yields worthwhile insights, this study also highlights the limitations of such an approach. Consequently, there is a need for the collection and analysis of new samples on OC content, dry bulk density, sedimentation rates, and ancillary parameters (e.g. grain size). Sampling design might be guided by the uncertainty maps provided here. The information gain that additional data could give is expected to be highest in areas of high predictive uncertainty. Reducing uncertainty in predictions might have large economic benefits, as has recently been demonstrated for the biological carbon pump (Jin et al., 2020). These authors developed an analytical model of the economic effects of global carbon emissions including uncertainty about biological carbon pump sequestration and estimated that the benefit to narrow the range of uncertainty about ocean carbon sequestration is on the order of USD 0.5 trillion. It may be assumed that sizeable economic benefits could also be achieved by reducing the uncertainty in the predictions of seafloor OC stocks and accumulation rates.

Alternatively, if the goal were to create a new baseline dataset covering the whole North Sea and Skagerrak, this might be best achieved by sampling the environmental variable space in a representative way. The relative importance of environmental variables on the distribution of OC is relatively well known both based on general knowledge and the results of this and other modelling studies. Several methods for optimising sampling design exist, including generalised random tessellation stratified sampling (Stevens and Olsen, 2003) and conditioned Latin hypercube sampling (Minasny and McBratney, 2006), among others. These could be utilised to effectively sample seafloor sediments, thereby minimising sampling effort and prediction uncertainty at the same time. Finally, future process studies might compare results from different zones of OC processing as shown in Fig. 7.

Further gains could be achieved by the standardisation of the collection of OC measurements. This includes sampling methods, the measured sediment fraction, defined depth horizons, and the reporting of results, among others. Such a standardisation would increase the comparability of the collected data and could be modelled on the experience of the global soil mapping community (Hengl et al., 2014). Although facilities to store and retrieve quality-controlled seafloor data centrally exist (e.g. EMODnet, ICES), it would still be advantageous to establish global data archives that are more specific to marine sedimentary carbon such as MOSAIC (van der Voort et al., 2020).
Finally, it would be desirable to complement OC data with measurements on $\mathrm{C} / \mathrm{N}$ ratios and $\delta^{13} \mathrm{C}$ to estimate the marine versus terrigenous fraction of OC (e.g. Faust and Knies, 2019). A quantification of the autochthonous and allochthonous OC contributions could be achieved with a two-endmember mixing model (Thornton and McManus, 1994). Knowledge of the sources of OC is required for a better understanding of OC sequestration in shelf sediments but would also be a basic requirement in the context of carbon offset credits (Macreadie et al., 2019), should such a system be extended to include shelf sediments. For example, the Verified Carbon Standard VM0033 (https://verra.org/methodology/vm0033-methodology-fortidal-wetland-and-seagrass-restoration-v1-0/, last access: 22 March 2021), the first voluntary market methodology for blue carbon ecosystems, stipulates that offset credits are not allocated under the framework for allochthonous OC because of the risk of duplicating $\mathrm{C}$ sequestration gains that may have been accounted for in adjacent ecosystems (Macreadie et al., 2019).

\section{Conclusions}

This work highlights distinct zones of OC processing at the seafloor of the North Sea and Skagerrak. While rapid OC processing and turnover are commonplace in the southern and eastern parts of the North Sea, the Norwegian Trough stands out as a hotspot of OC accumulation with rates comparable with nearby fjords. We expect that this dual character of the continental shelf in terms of OC processing and storage can be found across the global continental shelf, requiring further detailed and spatially explicit analyses to constrain sedimentary OC stocks and accumulation rates globally. Such estimates are urgently needed to better understand the potential of shelf sediments as a natural climate solution, e.g. by protecting suitable areas against human disturbance. 


\section{Appendix A}
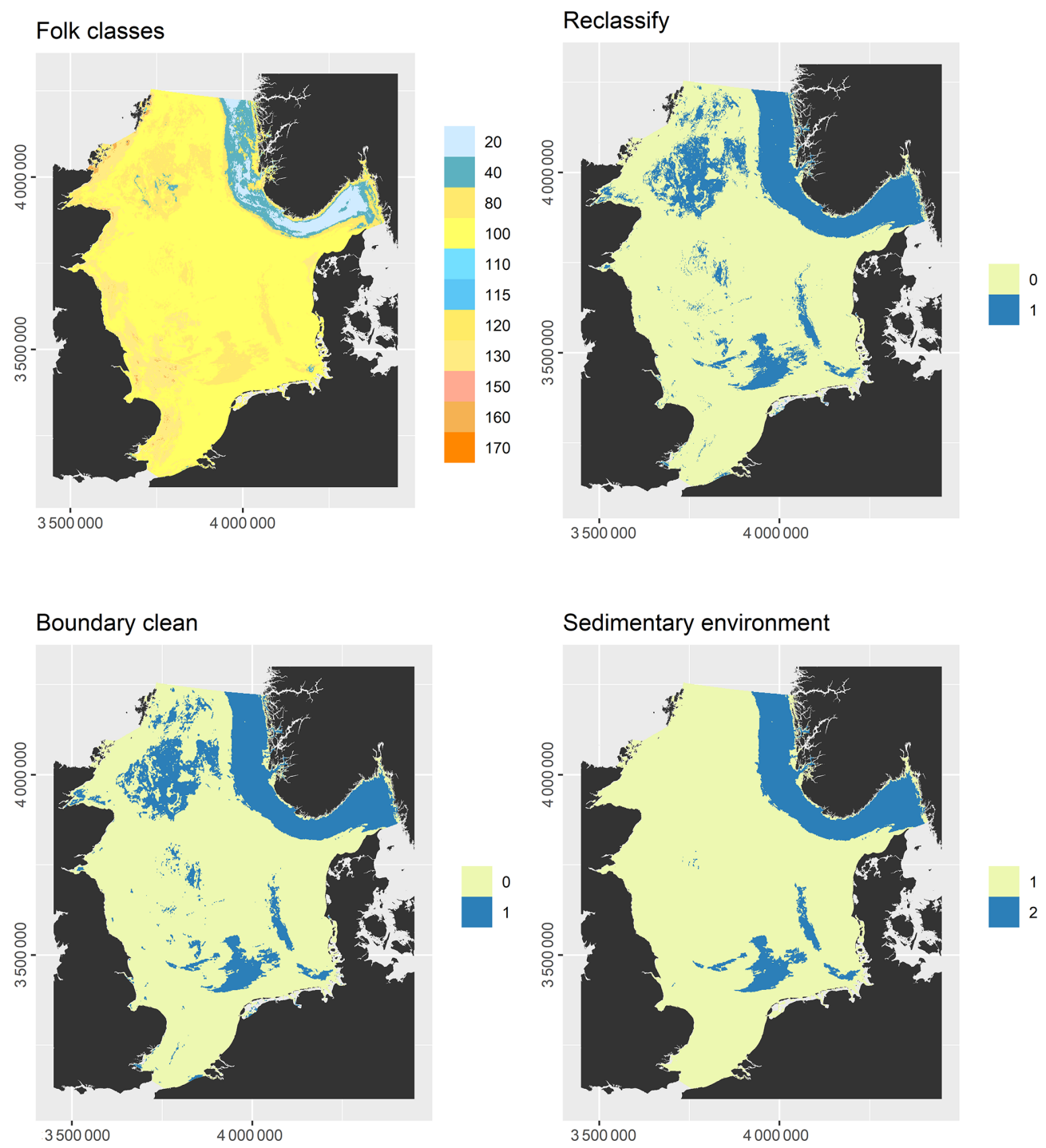

Figure A1. Derivation of the sedimentary environment layer: Folk textural classes were derived from sediment composition predicted by Mitchell et al. (2019a). 20 - mud, 40 - sandy mud, 80 - muddy sand, 100 - sand, 110 - gravelly mud, 115 - gravelly sandy mud, 120 gravelly muddy sand, 130 - gravelly sand, 150 - muddy sandy gravel, 160 - sandy gravel, 170 - gravel. Mud, sandy mud, and muddy sand were reclassified as potential accumulation (1), the remainder as erosion/non-deposition (0) areas. The polygons were simplified with the "Boundary Clean" tool in ArcGIS. The potential accumulation areas were critically reviewed in the light of measured sedimentation rates and geological interpretations of sediment cores (de Haas et al., 1997, and references therein) and the dominant areas of erosion/net-deposition (1) and sediment accumulation (2). 

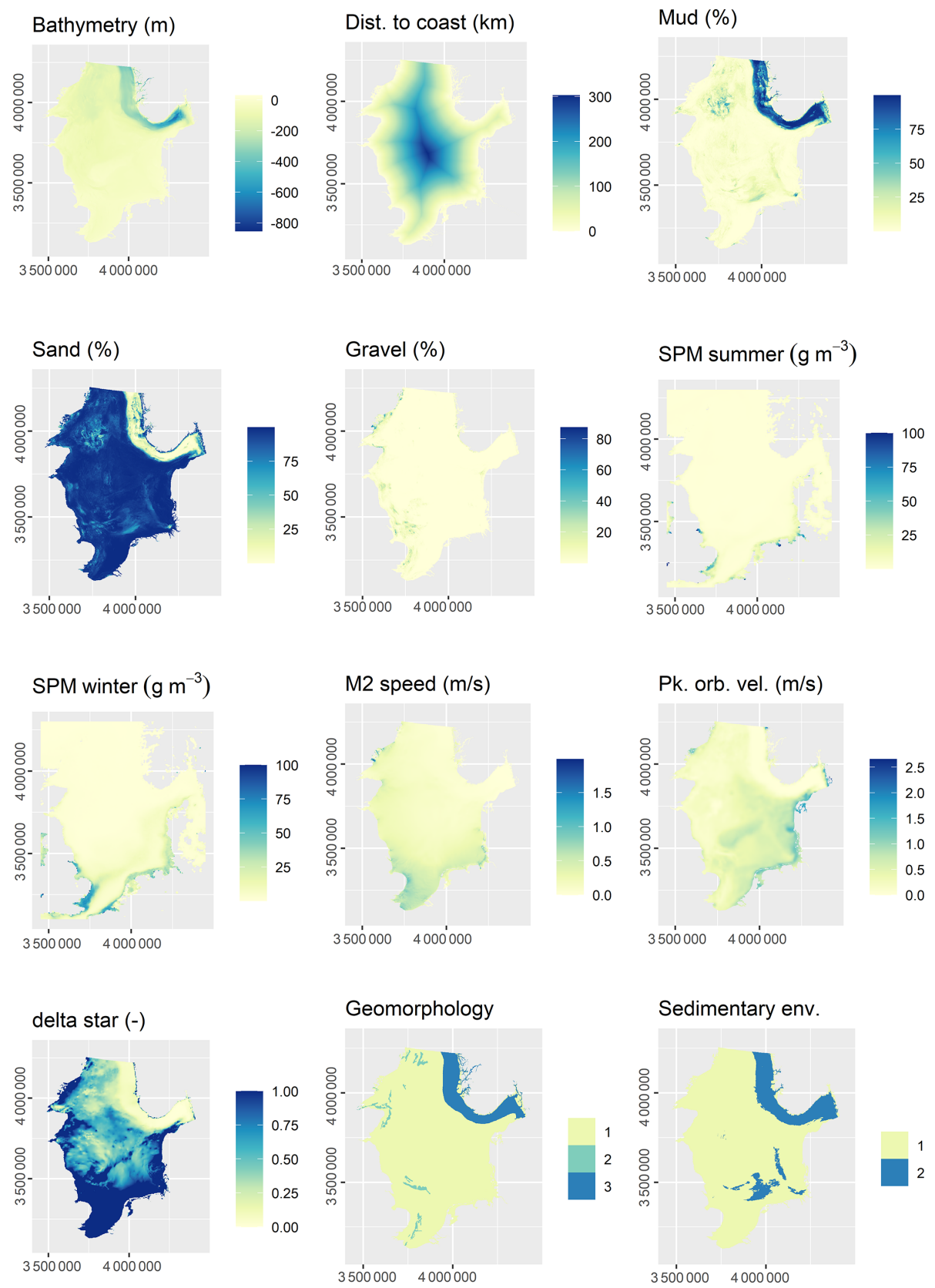

Figure A2. Selected predictor variables of the sedimentation rate model. Geomorphology: 1 - shelf, 2 - shelf valley, and 3 - glacial trough. Sedimentary environment: 1 - erosion/non-deposition and 2 - accumulation. 

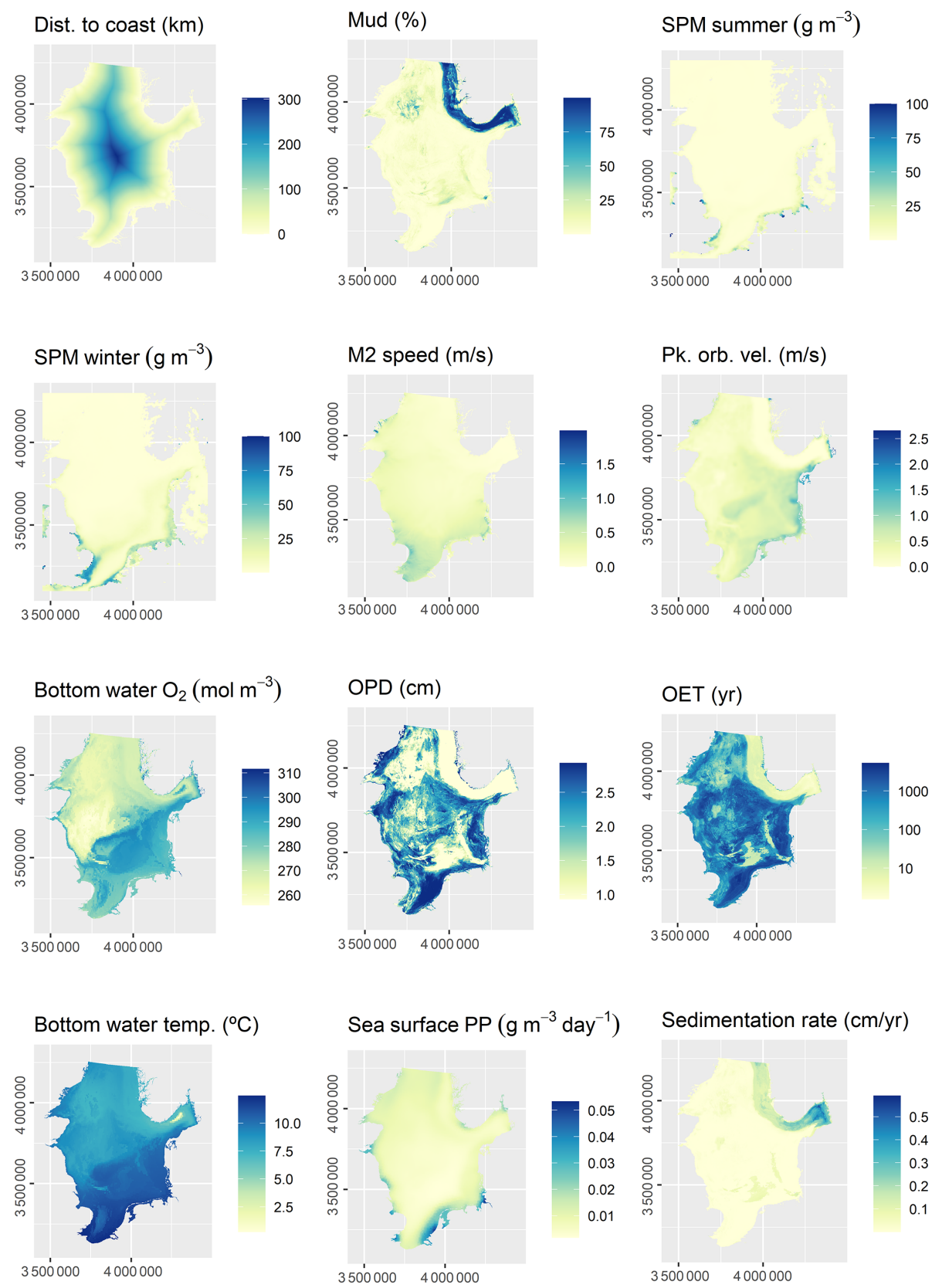

Figure A3. Selected predictor variables of the OC density model. Bathymetry was also selected but is not shown here. 
Code availability. The following $\mathrm{R}$ Markdown documents are provided as Supplement:

$$
\begin{aligned}
& \text { - File S1: Sedimentation Rates and Uncertainty, } \\
& \text { - File S2: Organic Carbon Density and Uncertainty, } \\
& \text { - File S3: Organic Carbon Accumulation Rates and Uncertainty, } \\
& \text { - File S4: Regionalisation of the Environment. }
\end{aligned}
$$

Data availability. Grids of sedimentation rates, OC density, OC accumulation rates, and their associated uncertainties are available on the PANGAEA website: https://doi.org/10.1594/PANGAEA.928272 (Diesing, 2021).

Supplement. The following data tables are provided as supplements. Supplementary Data Table 1: linear sedimentation rates. Supplementary Data Table 2: organic carbon densities. The supplement related to this article is available online at: https://doi.org/10.5194/bg-18-2139-2021-supplement.

Author contributions. MD, TT and LRB conceptualised the work; MD curated the data; MD carried out the analysis; TT and LRB acquired the funding; MD was responsible for the investigation; MD developed the methodology; LRB and TT administered the project; MD validated the results; MD visualised the results; MD wrote the original draft; MD, TT and LRB edited the paper after review.

Competing interests. The authors declare that they have no conflict of interest.

Acknowledgements. The authors thank Peter Mitchell for insightful discussions about the spatial prediction of sedimentation rates and the reviewers for valuable suggestions and comments that improved the quality of the paper.

Financial support. This study was financed by the Norwegian seabed mapping programme MAREANO.

Review statement. This paper was edited by Jack Middelburg and reviewed by Corallie Hunt and two anonymous referees.

\section{References}

Aldridge, J. N., Parker, E. R., Bricheno, L., Green, S. L., and van der Molen, J.: Assessment of the physical disturbance of the northern European Continental shelf seabed by waves and currents, Cont. Shelf Res., 108, 121-140, https://doi.org/10.1016/j.csr.2015.03.004, 2015.

Aller, R. C.: Sedimentary Diagenesis, Depositional Environments, and Benthic Fluxes, in: Treatise on Geochemistry, Elsevier,
293-334, https://doi.org/10.1016/B978-0-08-095975-7.00611-2, 2014.

Amoroso, R. O., Pitcher, C. R., Rijnsdorp, A. D., McConnaughey, R. A., Parma, A. M., Suuronen, P., Eigaard, O. R., Bastardie, F., Hintzen, N. T., Althaus, F., Baird, S. J., Black, J., BuhlMortensen, L., Campbell, A. B., Catarino, R., Collie, J., Cowan, J. H., Durholtz, D., Engstrom, N., Fairweather, T. P., Fock, H. O., Ford, R., Gálvez, P. A., Gerritsen, H., Góngora, M. E., González, J. A., Hiddink, J. G., Hughes, K. M., Intelmann, S. S., Jenkins, C., Jonsson, P., Kainge, P., Kangas, M., Kathena, J. N., Kavadas, S., Leslie, R. W., Lewis, S. G., Lundy, M., Makin, D., Martin, J., Mazor, T., Gonzalez-Mirelis, G., Newman, S. J., Papadopoulou, N., Posen, P. E., Rochester, W., Russo, T., Sala, A., Semmens, J. M., Silva, C., Tsolos, A., Vanelslander, B., Wakefield, C. B., Wood, B. A., Hilborn, R., Kaiser, M. J., and Jennings, S.: Bottom trawl fishing footprints on the world's continental shelves, P. Natl. Acad. Sci. USA, 115, E10275-E10282, https://doi.org/10.1073/pnas.1802379115, 2018.

Anonymous: Integrated Management of the Marine Environment of the North Sea and Skagerrak (Management Plan). Meld. St. 37 (2012-2013) Report to the Storting (white paper), available at: https://www.regjeringen.no/ contentassets/f9eb7ce889be4f47b5a2df5863b1be3d/en-gb/ pdfs/stm201220130037000engpdfs.pdf (last access: 15 September 2020), 2013.

Assis, J., Tyberghein, L., Bosch, S., Verbruggen, H., Serrão, E. A., and De Clerck, O.: Bio-ORACLE v2.0: Extending marine data layers for bioclimatic modelling, Glob. Ecol. Biogeogr., 27, 277284, https://doi.org/10.1111/geb.12693, 2018.

Atwood, T. B., Witt, A., Mayorga, J., Hammill, E., and Sala, E.: Global Patterns in Marine Sediment Carbon Stocks, Front. Mar Sci., 7, 165, https://doi.org/10.3389/fmars.2020.00165, 2020.

Avelar, S., van der Voort, T. S., and Eglinton, T. I.: Relevance of carbon stocks of marine sediments for national greenhouse gas inventories of maritime nations, Carbon Balance Manag., 12, 10, https://doi.org/10.1186/s13021-017-0077-x, 2017.

Bakker, J. F. and Helder, W.: Skagerrak (northeastern North Sea) oxygen microprofiles and porewater chemistry in sediments, Mar. Geol., 111, 299-321, https://doi.org/10.1016/00253227(93)90137-K, 1993.

Balzer, W.: Organic matter degradation and biogenic element cycling in a nearshore sediment (Kiel Bight)1, Limnol. Oceanogr., 29, 1231-1246, https://doi.org/10.4319/lo.1984.29.6.1231, 1984.

Bauer, J. E., Cai, W.-J., Raymond, P. A., Bianchi, T. S., Hopkinson, C. S., and Regnier, P. A. G.: The changing carbon cycle of the coastal ocean, Nature, 504, 61-70, 2013.

Berner, R. A.: Early diagenesis: A theoretical approach, Princeton University Press, Princeton, N.J., 1980.

Berner, R. A.: Burial of organic carbon and pyrite sulfur in the modern ocean: Its geochemical and environmental significance, Am. J. Sci., 282, 451-473, https://doi.org/10.2475/ajs.282.4.451, 1982.

Bhagirathan, U., Meenakumari, B., Jayalakshmy, K. V, Panda, S. K., Madhu, V. R., and Vaghela, D. T.: Impact of bottom trawling on sediment characteristics - a study along inshore waters off Veraval coast, India, Environ. Monit. Assess., 160, 355-369, https://doi.org/10.1007/s10661-008-0700-0, 2010. 
Bianchi, T. S., Cui, X., Blair, N. E., Burdige, D. J., Eglinton, T. I., and Galy, V.: Centers of organic carbon burial and oxidation at the land-ocean interface, Org. Geochem., 115, 138-155, https://doi.org/10.1016/j.orggeochem.2017.09.008, 2018.

De Borger, E., Tiano, J., Braeckman, U., Rijnsdorp, A. D., and Soetaert, K.: Impact of bottom trawling on sediment biogeochemistry: a modelling approach, Biogeosciences Discuss. [preprint], https://doi.org/10.5194/bg-2020-328, in review, 2020.

Breiman, L.: Random Forests, Mach. Learn., 45, 5-32, 2001.

Burdige, D. J.: Preservation of Organic Matter in Marine Sediments: Controls, Mechanisms, and an Imbalance in Sediment Organic Carbon Budgets?, Chem. Rev., 107, 467-485, https://doi.org/10.1021/cr050347q, 2007.

Canfield, D. E.: Factors influencing organic carbon preservation in marine sediments, Chem. Geol., 114, 315-329, https://doi.org/10.1016/0009-2541(94)90061-2, 1994.

de Haas, H. and van Weering, T. C. E.: Recent sediment accumulation, organic carbon burial and transport in the northeastern North Sea, Mar. Geol., 136, 173-187, https://doi.org/10.1016/S0025-3227(96)00072-2, 1997.

de Haas, H., Boer, W., and van Weering, T. C. E.: Recent sedimentation and organic carbon burial in a shelf sea: the North Sea, Mar. Geol., 144, 131-146, https://doi.org/10.1016/S00253227(97)00082-0, 1997.

de Haas, H., van Weering, T. C. E., and de Stigter, H.: Organic carbon in shelf seas: sinks or sources, processes and products, Cont. Shelf Res., 22, 691-717, https://doi.org/10.1016/S02784343(01)00093-0, 2002.

Diesing, M.: Spatially predicted sedimentation rates, organic carbon densities and organic carbon accumulation rates in the North Sea and Skagerrak, PANGAEA, https://doi.org/10.1594/PANGAEA.928272, 2021.

Diesing, M., Kröger, S., Parker, R., Jenkins, C., Mason, C., and Weston, K.: Predicting the standing stock of organic carbon in surface sediments of the North-West European continental shelf, Biogeochemistry, 135, 183-200, https://doi.org/10.1007/s10533017-0310-4, 2017.

Duarte, C. M., Middelburg, J. J., and Caraco, N.: Major role of marine vegetation on the oceanic carbon cycle, Biogeosciences, 2 , 1-8, https://doi.org/10.5194/bg-2-1-2005, 2005.

Duarte, C. M., Losada, I. J., Hendriks, I. E., Mazarrasa, I., and Marbà, N.: The role of coastal plant communities for climate change mitigation and adaptation, Nat. Clim. Change, 3, 961968, https://doi.org/10.1038/nclimate1970, 2013.

Eigaard, O. R., Bastardie, F., Hintzen, N. T., Buhl-Mortensen, L., Buhl-Mortensen, P., Catarino, R., Dinesen, G. E., Egekvist, J., Fock, H. O., Geitner, K., Gerritsen, H. D., González, M. M., Jonsson, P., Kavadas, S., Laffargue, P., Lundy, M., Gonzalez-Mirelis, G., Nielsen, J. R., Papadopoulou, N., Posen, P. E., Pulcinella, J., Russo, T., Sala, A., Silva, C., Smith, C. J., Vanelslander, B., and Rijnsdorp, A. D.: The footprint of bottom trawling in European waters: distribution, intensity, and seabed integrity, ICES J. Mar. Sci., 74, 847-865, https://doi.org/10.1093/icesjms/fsw194, 2016.

Eisma, D. and Kalf, J.: Dispersal, concentration and deposition of suspended matter in the North Sea., J. Geol. Soc. London, 144, 161-178, https://doi.org/10.1144/gsjgs.144.1.0161, 1987.

Elvenes, S., Bøe, R., Lepland, A., and Dolan, M.: Seabed sediments of Søre Sunnmøre, Norway, J. Maps, 15, 686-696, https://doi.org/10.1080/17445647.2019.1659865, 2019.
Emery, K. O.: Relict sediments on continental shelves of world, Am. Assoc. Petr. Geol. Bull., 52, 445-464, 1968.

"EMODnet Bathymetry Consortium": EMODnet Digital Bathymetry (DTM 2018), https://doi.org/10.12770/18ff0d48b203-4a65-94a9-5fd8b0ec35f6, 2018.

Faust, J. C. and Knies, J.: Organic Matter Sources in North Atlantic Fjord Sediments, Geochem. Geophy. Geosy., 20, 28722885, https://doi.org/10.1029/2019GC008382, 2019.

Fennel, K., Alin, S., Barbero, L., Evans, W., Bourgeois, T., Cooley, S., Dunne, J., Feely, R. A., Hernandez-Ayon, J. M., Hu, X., Lohrenz, S., Muller-Karger, F., Najjar, R., Robbins, L., Shadwick, E., Siedlecki, S., Steiner, N., Sutton, A., Turk, D., Vlahos, P., and Wang, Z. A.: Carbon cycling in the North American coastal ocean: a synthesis, Biogeosciences, 16, 1281-1304, https://doi.org/10.5194/bg-16-1281-2019, 2019.

Griscom, B. W., Adams, J., Ellis, P. W., Houghton, R. A., Lomax, G., Miteva, D. A., Schlesinger, W. H., Shoch, D., Siikamäki, J. V, Smith, P., Woodbury, P., Zganjar, C., Blackman, A., Campari, J., Conant, R. T., Delgado, C., Elias, P., Gopalakrishna, T., Hamsik, M. R., Herrero, M., Kiesecker, J., Landis, E., Laestadius, L., Leavitt, S. M., Minnemeyer, S., Polasky, S., Potapov, P., Putz, F. E., Sanderman, J., Silvius, M., Wollenberg, E., and Fargione, J.: Natural climate solutions, P. Natl. Acad. Sci. USA, 114, 1164511650, https://doi.org/10.1073/pnas.1710465114, 2017.

Guevara, M., Thine, C., Olmedo, G. F., and Vargas, R. R.: Data mining: random forest, in: Soil Organic Carbon Mapping Cookbook, edited by: Yigini, Y., Olmedo, G. F., Reiter, S., Baritz, R., Viatkin, K., and Vargas, R., FAO, Rome, 83-98,2018.

Guisan, A. and Zimmermann, N. E.: Predictive habitat distribution models in ecology, Ecol. Model., 135, 147-186, https://doi.org/10.1016/S0304-3800(00)00354-9, 2000.

Hall, S. J.: The continental shelf benthic ecosystem: current status, agents for change and future prospects, Environ. Conserv., 29, 350-374, https://doi.org/10.1017/S0376892902000243, 2002.

Halpern, B. S., Walbridge, S., Selkoe, K. A., Kappel, C. V, Micheli, F., D’Agrosa, C., Bruno, J. F., Casey, K. S., Ebert, C., Fox, H. E., Fujita, R., Heinemann, D., Lenihan, H. S., Madin, E. M. P., Perry, M. T., Selig, E. R., Spalding, M., Steneck, R., and Watson, R.: A Global Map of Human Impact on Marine Ecosystems, Science, 319, 948-952, https://doi.org/10.1126/science.1149345, 2008.

Harris, P. T., Macmillan-Lawler, M., Rupp, J., and Baker, E. K.: Geomorphology of the oceans, Mar. Geol., 352, 4-24, https://doi.org/10.1016/j.margeo.2014.01.011, 2014.

Hartigan, J. A. and Wong, M. A.: Algorithm AS 136: A K-Means Clustering Algorithm, J. R. Stat. Soc. Ser. C-Appl., 28, 100-108, https://doi.org/10.2307/2346830, 1979.

Hartnett, H. E., Keil, R. G., Hedges, J. I., and Devol, A. H.: Influence of oxygen exposure time on organic carbon preservation in continental margin sediments, Nature, 391, 572, https://doi.org/10.1038/35351, 1998.

Hedges, J. I. and Keil, R. G.: Sedimentary organic matter preservation: an assessment and speculative synthesis, Mar. Chem., 49, 81-115, https://doi.org/10.1016/0304-4203(95)00008-F, 1995.

Hemingway, J. D., Rothman, D. H., Grant, K. E., Rosengard, S. Z., Eglinton, T. I., Derry, L. A., and Galy, V. V.: Mineral protection regulates long-term global preservation of natural organic carbon, Nature, 570, 228-231, https://doi.org/10.1038/s41586-0191280-6, 2019. 
Hengl, T., de Jesus, J. M., MacMillan, R. A., Batjes, N. H., Heuvelink, G. B. M., Ribeiro, E., Samuel-Rosa, A., Kempen, B., Leenaars, J. G. B., Walsh, M. G., and Gonzalez, M. R.: SoilGrids1km - Global Soil Information Based on Automated Mapping, Plos One, 9, e105992, https://doi.org/10.1371/journal.pone.0105992, 2014.

Hengl, T., de Jesus, J., Heuvelink, G. B. M., Ruiperez Gonzalez, M., Kilibarda, M., Blagotić, A., Shangguan, W., Wright, M. N., Geng, X., Bauer-Marschallinger, B., Guevara, M. A., Vargas, R., MacMillan, R. A., Batjes, N. H., Leenaars, J. G. B., Ribeiro, E., Wheeler, I., Mantel, S., and Kempen, B.: SoilGrids250m: Global gridded soil information based on machine learning, Plos One, 12, 1-40, https://doi.org/10.1371/journal.pone.0169748, 2017.

Hengl, T., Nussbaum, M., Wright, M. N., Heuvelink, G. B. M., and Gräler, B.: Random forest as a generic framework for predictive modeling of spatial and spatio-temporal variables, PeerJ, 6, e5518, https://doi.org/10.7717/peerj.5518, 2018.

Hiddink, J. G., Jennings, S., and Kaiser, M. J.: Indicators of the Ecological Impact of Bottom-Trawl Disturbance on Seabed Communities, Ecosystems, 9, 1190-1199, https://doi.org/10.1007/s10021-005-0164-9, 2006.

Hiddink, J. G., Jennings, S., Sciberras, M., Szostek, C. L., Hughes, K. M., Ellis, N., Rijnsdorp, A. D., McConnaughey, R. A., Mazor, T., Hilborn, R., Collie, J. S., Pitcher, C. R., Amoroso, R. O., Parma, A. M., Suuronen, P., and Kaiser, M. J.: Global analysis of depletion and recovery of seabed biota after bottom trawling disturbance, P. Natl. Acad. Sci. USA, 114, 8301-8306, https://doi.org/10.1073/pnas.1618858114, 2017.

Huettel, M. and Rusch, A.: Transport and degradation of phytoplankton in permeable sediment, Limnol. Oceanogr., 45, 534549, https://doi.org/10.4319/lo.2000.45.3.0534, 2000.

Huettel, M., Ziebis, W., and Forster, S.: Flow-induced uptake of particulate matter in permeable sediments, Limnol. Oceanogr., 41, 309-322, https://doi.org/10.4319/lo.1996.41.2.0309, 1996.

Huettel, M., Roy, H., Precht, E., and Ehrenhauss, S.: Hydrodynamical impact on biogeochemical processes in aquatic sediments, Hydrobiologia, 494, 231-236, 2003.

Huettel, M., Berg, P., and Kostka, J. E.: Benthic Exchange and Biogeochemical Cycling in Permeable Sediments, Ann. Rev. Mar. Sci., 6, 23-51, https://doi.org/10.1146/annurev-marine-051413012706, 2014.

Huguet, C., Smittenberg, R. H., Boer, W., Sinninghe Damsté, J. S., and Schouten, S.: Twentieth century proxy records of temperature and soil organic matter input in the Drammensfjord, southern Norway, Org. Geochem., 38, 1838-1849, https://doi.org/10.1016/j.orggeochem.2007.06.015, 2007.

Hunt, C., Demšar, U., Dove, D., Smeaton, C., Cooper, R., and Austin, W. E. N.: Quantifying Marine Sedimentary Carbon: A New Spatial Analysis Approach Using Seafloor Acoustics, Imagery, and Ground-Truthing Data in Scotland, Front. Mar. Sci., 7, 588, https://doi.org/10.3389/fmars.2020.00588, 2020.

International Hydrographic Organization: Limits of oceans and seas, IHO Spec. Publ., 28, 39 pp., 1953.

Jenkins, C.: Sediment Accumulation Rates For the Mississippi Delta Region: a Time-interval Synthesis, J. Sediment. Res., 88, 301-309, https://doi.org/10.2110/jsr.2018.15, 2018.

Jennerjahn, T. C.: Relevance and magnitude of "Blue Carbon" storage in mangrove sediments: Carbon accumulation rates vs. stocks, sources vs. sinks, Estuar. Coast. Shelf Sci., 247, 107027, https://doi.org/10.1016/j.ecss.2020.107027, 2020.

Jennings, S., Dinmore, T. A., Duplisea, D. E., Warr, K. J., and Lancaster, J. E.: Trawling disturbance can modify benthic production processes, J. Anim. Ecol., 70, 459-475, https://doi.org/10.1046/j.1365-2656.2001.00504.x, 2001.

Jin, D., Hoagland, P., and Buesseler, K. O.: The value of scientific research on the ocean's biological carbon pump, Sci. Total Environ., 749, 141357, https://doi.org/10.1016/j.scitotenv.2020.141357, 2020.

Jørgensen, B., Bang, M., and Blackburn, T.: Anaerobic mineralization in marine sediments from the Baltic SeaNorth Sea transition, Mar. Ecol. Prog. Ser., 59, 39-54, https://doi.org/10.3354/meps059039, 1990.

Jørgensen, B. B.: The sulfur cycle of a coastal marine sediment (Limfjorden, Denmark)1, Limnol. Oceanogr., 22, 814-832, https://doi.org/10.4319/lo.1977.22.5.0814, 1977.

Keil, R.: Hoard of fjord carbon, Nat. Geosci., 8, 426, https://doi.org/10.1038/ngeo2433, 2015.

Keil, R.: Anthropogenic Forcing of Carbonate and Organic Carbon Preservation in Marine Sediments, Ann. Rev. Mar. Sci., 9, 151172, https://doi.org/10.1146/annurev-marine-010816-060724, 2017.

Keil, R. G. and Hedges, J. I.: Sorption of organic matter to mineral surfaces and the preservation of organic matter in coastal marine sediments, Chem. Geol., 107, 385-388, https://doi.org/10.1016/0009-2541(93)90215-5, 1993.

Köchy, M., Hiederer, R., and Freibauer, A.: Global distribution of soil organic carbon - Part 1: Masses and frequency distributions of SOC stocks for the tropics, permafrost regions, wetlands, and the world, SOIL, 1, 351-365, https://doi.org/10.5194/soil-1-3512015, 2015.

Krause-Jensen, D. and Duarte, C. M.: Substantial role of macroalgae in marine carbon sequestration, Nat. Geosci, 9, 737-742, https://doi.org/10.1038/ngeo2790, 2016.

Kursa, M. and Rudnicki, W.: Feature selection with the Boruta Package, J. Stat. Softw., 36, 1-11, 2010.

LaRowe, D. E., Arndt, S., Bradley, J. A., Burwicz, E., Dale, A. W., and Amend, J. P.: Organic carbon and microbial activity in marine sediments on a global scale throughout the Quaternary, Geochim. Cosmochim. Ac., 286, 227-247, https://doi.org/10.1016/j.gca.2020.07.017, 2020.

Lee, T. R., Wood, W. T., and Phrampus, B. J.: A Machine Learning $(\mathrm{kNN})$ Approach to Predicting Global Seafloor Total Organic Carbon, Global Biogeochem. Cy., 33, 37-46, https://doi.org/10.1029/2018GB005992, 2019.

Legge, O., Johnson, M., Hicks, N., Jickells, T., Diesing, M., Aldridge, J., Andrews, J., Artioli, Y., Bakker, D. C. E., Burrows, M. T., Carr, N., Cripps, G., Felgate, S. L., Fernand, L., Greenwood, N., Hartman, S., Kröger, S., Lessin, G., Mahaffey, C., Mayor, D. J., Parker, R., Queirós, A. M., Shutler, J. D., Silva, T., Stahl, H., Tinker, J., Underwood, G. J. C., Van Der Molen, J., Wakelin, S., Weston, K., and Williamson, P.: Carbon on the Northwest European Shelf: Contemporary Budget and Future Influences, Front. Mar. Sci., 7, 143, https://doi.org/10.3389/fmars.2020.00143, 2020.

Leipe, T., Tauber, F., Vallius, H., Virtasalo, J., Uścinowicz, S., Kowalski, N., Hille, S., Lindgren, S., and Myllyvirta, T.: Particulate organic carbon (POC) in surface sediments of the Baltic Sea, 
Geo-Marine Lett., 31, 175-188, https://doi.org/10.1007/s00367010-0223-x, 2011.

Luisetti, T., Turner, R. K., Andrews, J. E., Jickells, T. D., Kröger, S., Diesing, M., Paltriguera, L., Johnson, M. T., Parker, E. R., Bakker, D. C. E., and Weston, K.: Quantifying and valuing carbon flows and stores in coastal and shelf ecosystems in the UK, Ecosyst. Serv., 35, 67-76, https://doi.org/10.1016/J.ECOSER.2018.10.013, 2019.

Luisetti, T., Ferrini, S., Grilli, G., Jickells, T. D., Kennedy, H., Kröger, S., Lorenzoni, I., Milligan, B., van der Molen, J., Parker, R., Pryce, T., Turner, R. K., and Tyllianakis, E.: Climate action requires new accounting guidance and governance frameworks to manage carbon in shelf seas, Nat. Commun., 11, 4599, https://doi.org/10.1038/s41467-020-18242-w, 2020.

Macreadie, P. I., Anton, A., Raven, J. A., Beaumont, N., Connolly, R. M., Friess, D. A., Kelleway, J. J., Kennedy, H., Kuwae, T., Lavery, P. S., Lovelock, C. E., Smale, D. A., Apostolaki, E. T., Atwood, T. B., Baldock, J., Bianchi, T. S., Chmura, G. L., Eyre, B. D., Fourqurean, J. W., Hall-Spencer, J. M., Huxham, M., Hendriks, I. E., Krause-Jensen, D., Laffoley, D., Luisetti, T., Marbà, N., Masque, P., McGlathery, K. J., Megonigal, J. P., Murdiyarso, D., Russell, B. D., Santos, R., Serrano, O., Silliman, B. R., Watanabe, K., and Duarte, C. M.: The future of Blue Carbon science, Nat. Commun., 10, 3998, https://doi.org/10.1038/s41467019-11693-w, 2019.

Martens, C. S. and Val Klump, J.: Biogeochemical cycling in an organic-rich coastal marine basin 4. An organic carbon budget for sediments dominated by sulfate reduction and methanogenesis, Geochim. Cosmochim. Ac., 48, 1987-2004, https://doi.org/10.1016/0016-7037(84)90380-6, 1984.

Martín, J., Puig, P., Palanques, A., and Giamportone, A.: Commercial bottom trawling as a driver of sediment dynamics and deep seascape evolution in the Anthropocene, Anthropocene, 7, 1-15, https://doi.org/10.1016/j.ancene.2015.01.002, 2014a.

Martín, J., Puig, P., Masqué, P., Palanques, A., and Sánchez-Gómez, A.: Impact of Bottom Trawling on Deep-Sea Sediment Properties along the Flanks of a Submarine Canyon, Plos One, 9, 1-11, https://doi.org/10.1371/journal.pone.0104536, 2014b.

Mayer, L. M.: Surface area control of organic carbon accumulation in continental shelf sediments, Geochim. Cosmochim. Ac., 58, 1271-1284, https://doi.org/10.1016/0016-7037(94)90381-6, 1994.

McBratney, A. B., Mendonça Santos, M. L., and Minasny, B.: On digital soil mapping, Geoderma, 117, 3-52, https://doi.org/10.1016/S0016-7061(03)00223-4, 2003.

Mcleod, E., Chmura, G. L., Bouillon, S., Salm, R., Björk, M., Duarte, C. M., Lovelock, C. E., Schlesinger, W. H., and Silliman, B. R.: A blueprint for blue carbon: toward an improved understanding of the role of vegetated coastal habitats in sequestering $\mathrm{CO}_{2}$, Front. Ecol. Environ., 9, 552-560, https://doi.org/10.1890/110004, 2011.

Meinshausen, N.: Quantile Regression Forests, J. Mach. Learn. Res., 7, 983-999, 2006.

Middelburg, J. J.: Carbon Processing at the Seafloor, in Marine Carbon Biogeochemistry: A Primer for Earth System Scientists, Springer International Publishing, Cham, 57-75, 2019.

Middelburg, J. J., Soetaert, K., and Herman, P. M. J.: Empirical relationships for use in global diagenetic models,
Deep Sea Res. Part I Oceanogr. Res. Pap., 44, 327-344, https://doi.org/10.1016/S0967-0637(96)00101-X, 1997.

Minasny, B. and McBratney, A. B.: A conditioned Latin hypercube method for sampling in the presence of ancillary information, Comput. Geosci., 32, 1378-1388, https://doi.org/10.1016/J.CAGEO.2005.12.009, 2006.

Mitchell, P. J., Aldridge, J., and Diesing, M.: Legacy data: How decades of seabed sampling can produce robust predictions and versatile products, Geosciences J., 9, 182, https://doi.org/10.3390/geosciences9040182, 2019a.

Mitchell, P., Aldridge, J., and Diesing, M.: Quantitative sediment composition predictions for the northwest European continental shelf, Cefas, UK, V1, https://doi.org/10.14466/CefasDataHub.63, 2019b.

Mitchell, P., Aldridge, J., and Diesing, M.: Predictor variables and groundtruth samples for north-west European continental shelf quantitative sediment analysis, Cefas, UK, V1, https://doi.org/10.14466/CefasDataHub.62, 2019c.

Mitchell, P. J., Spence, M. A., Aldridge, J., Kotilainen, A. T., and Diesing, M.: Sedimentation rates in the Baltic Sea: A machine learning approach, Cont. Shelf Res., 214, 104325, https://doi.org/10.1016/j.csr.2020.104325, 2021.

Miteva, D. A., Murray, B. C., and Pattanayak, S. K.: Do protected areas reduce blue carbon emissions? A quasi-experimental evaluation of mangroves in Indonesia, Ecol. Econ., 119, 127-135, https://doi.org/10.1016/j.ecolecon.2015.08.005, 2015.

Müller, A.: Geochemical expressions of anoxic conditions in Nordåsvannet, a land-locked fjord in western Norway, Appl. Geochemistry, 16, 363-374, https://doi.org/10.1016/S08832927(00)00024-X, 2001.

Müller, P. J. and Suess, E.: Productivity, sedimentation rate, and sedimentary organic matter in the oceans - I. Organic carbon preservation, Deep Sea Res. Pt. A., 26, 1347-1362, https://doi.org/10.1016/0198-0149(79)90003-7, 1979.

Najjar, R. G., Herrmann, M., Alexander, R., Boyer, E. W., Burdige, D. J., Butman, D., Cai, W.-J., Canuel, E. A., Chen, R. F., Friedrichs, M. A. M., Feagin, R. A., Griffith, P. C., Hinson, A. L., Holmquist, J. R., Hu, X., Kemp, W. M., Kroeger, K. D., Mannino, A., McCallister, S. L., McGillis, W. R., Mulholland, M. R., Pilskaln, C. H., Salisbury, J., Signorini, S. R., St-Laurent, P., Tian, H., Tzortziou, M., Vlahos, P., Wang, Z. A., and Zimmerman, R. C.: Carbon Budget of Tidal Wetlands, Estuaries, and Shelf Waters of Eastern North America, Global Biogeochem. Cy., 32, 389-416, https://doi.org/10.1002/2017GB005790, 2018.

Nellemann, C., Corcoran, E., Duarte, C. M., Valdés, L., De Young, C., Fonseca, L., and Grimsditch, G.: Blue Carbon: The Role of Healthy Oceans in Binding Carbon: A Rapid Response Assessment, available at: https://www.grida.no/publications/145 (last access: 22 March 2021), 2009.

Nordberg, K., Filipsson, H. L., Gustafsson, M., Harland, R., and Roos, P.: Climate, hydrographic variations and marine benthic hypoxia in Koljö Fjord, Sweden, J. Sea Res., 46, 187-200, https://doi.org/10.1016/S1385-1101(01)00084-3, 2001.

Nordberg, K., Filipsson, H. L., Linné, P., and Gustafsson, M.: Stable oxygen and carbon isotope information on the establishment of a new, opportunistic foraminiferal fauna in a Swedish Skagerrak fjord basin, in 1979/1980, Mar. Micropaleontol., 73, 117-128, https://doi.org/10.1016/j.marmicro.2009.07.006, 2009. 
Oberle, F. K. J., Storlazzi, C. D., and Hanebuth, T. J. J.: What a drag: Quantifying the global impact of chronic bottom trawling on continental shelf sediment, J. Mar. Syst., 159, 109-119, https://doi.org/10.1016/j.jmarsys.2015.12.007, 2016.

Palanques, A., Puig, P., Guillén, J., Demestre, M., and Martín, J.: Effects of bottom trawling on the Ebro continental shelf sedimentary system (NW Mediterranean), Cont. Shelf Res., 72, 83-98, https://doi.org/10.1016/j.csr.2013.10.008, 2014.

Paradis, S., Pusceddu, A., Masqué, P., Puig, P., Moccia, D., Russo, T., and Lo Iacono, C.: Organic matter contents and degradation in a highly trawled area during fresh particle inputs (Gulf of Castellammare, southwestern Mediterranean), Biogeosciences, 16, 4307-4320, https://doi.org/10.5194/bg-16-4307-2019, 2019.

Paradis, S., Goñi, M., Masqué, P., Durán, R., Arjona-Camas, M., Palanques, A., and Puig, P.: Persistence of Biogeochemical Alterations of Deep-Sea Sediments by Bottom Trawling, Geophys. Res. Lett., 48 , e2020GL091279, https://doi.org/10.1029/2020GL091279, 2020.

Paropkari, A. L., Prakash Babu, C., and Mascarenhas, A.: A critical evaluation of depositional parameters controlling the variability of organic carbon in Arabian Sea sediments, Mar. Geol., 107, 213-226, https://doi.org/10.1016/0025-3227(92)90168-H, 1992.

Precht, E. and Huettel, M.: Advective pore-water exchange driven by surface gravity waves and its ecological implications, Limnol. Oceanogr., 48, 1674-1684, 2003.

Pusceddu, A., Fiordelmondo, C., Polymenakou, P., Polychronaki, T., Tselepides, A., and Danovaro, R.: Effects of bottom trawling on the quantity and biochemical composition of organic matter in coastal marine sediments (Thermaikos Gulf, northwestern Aegean Sea), Cont. Shelf Res., 25, 2491-2505, https://doi.org/10.1016/j.csr.2005.08.013, 2005.

Pusceddu, A., Bianchelli, S., Martín, J., Puig, P., Palanques, A., Masqué, P., and Danovaro, R.: Chronic and intensive bottom trawling impairs deep-sea biodiversity and ecosystem functioning, P. Natl. Acad. Sci. USA, 111, 8861-8866, https://doi.org/10.1073/pnas.1405454111, 2014.

R Core Team: R: A Language and Environment for Statistical Computing, R Foundation for Statistical Computing, Vienna, Austria, available at: https://www.r-project.org/ (last access: 23 March 2021), 2018.

Roberts, C. M., O'Leary, B. C., McCauley, D. J., Cury, P. M., Duarte, C. M., Lubchenco, J., Pauly, D., Sáenz-Arroyo, A., Sumaila, U. R., Wilson, R. W., Worm, B., and Castilla, J. C.: Marine reserves can mitigate and promote adaptation to climate change, P. Natl. Acad. Sci. USA, 114, 6167-6175, https://doi.org/10.1073/pnas.1701262114, 2017.

Seiter, K., Hensen, C., Schröter, J., and Zabel, M.: Organic carbon content in surface sediments-defining regional provinces, Deep Sea Res. Pt. I, 51, 2001-2026, https://doi.org/10.1016/j.dsr.2004.06.014, 2004.

Skei, J.: Geochemical and sedimentological considerations of a permanently anoxic fjord - Framvaren, south Norway, Sediment. Geol., 36, 131-145, https://doi.org/10.1016/00370738(83)90006-4, 1983.

Smeaton, C. and Austin, W. E. N.: Where's the Carbon: Exploring the Spatial Heterogeneity of Sedimentary Carbon in Mid-Latitude Fjords, Front. Earth Sci., 7, 269, https://doi.org/10.3389/feart.2019.00269, 2019.
Smeaton, C., Austin, W. E. N., Davies, A. L., Baltzer, A., Abell, R. E., and Howe, J. A.: Substantial stores of sedimentary carbon held in mid-latitude fjords, Biogeosciences, 13, 5771-5787, https://doi.org/10.5194/bg-13-5771-2016, 2016.

Smeaton, C., Austin, W. E. N., Davies, A. L., Baltzer, A., Howe, J. A., and Baxter, J. M.: Scotland's forgotten carbon: a national assessment of mid-latitude fjord sedimentary carbon stocks, Biogeosciences, 14, 5663-5674, https://doi.org/10.5194/bg-145663-2017, 2017.

Smittenberg, R. H., Pancost, R. D., Hopmans, E. C., Paetzel, M., and Sinninghe Damsté, J. S.: A 400-year record of environmental change in an euxinic fjord as revealed by the sedimentary biomarker record, Palaeogeogr. Palaeoclimatol. Palaeoecol., 202, 331-351, https://doi.org/10.1016/S0031-0182(03)00642-4, 2004.

Smittenberg, R. H., Baas, M., Green, M. J., Hopmans, E. C., Schouten, S., and Sinninghe Damsté, J. S.: Pre- and postindustrial environmental changes as revealed by the biogeochemical sedimentary record of Drammensfjord, Norway, Mar. Geol., 214, 177-200, https://doi.org/10.1016/j.margeo.2004.10.029, 2005.

Steen, A. D., Quigley, L. N. M., and Buchan, A.: Evidence for the Priming Effect in a Planktonic Estuarine Microbial Community, Front. Mar. Sci., 3, 6, https://doi.org/10.3389/fmars.2016.00006, 2016.

Stevens Jr, D. L. and Olsen, A. R.: Variance estimation for spatially balanced samples of environmental resources, Environmetrics, 14, 593-610, https://doi.org/10.1002/env.606, 2003.

Thornton, S. F. and McManus, J.: Application of Organic Carbon and Nitrogen Stable Isotope and C/N Ratios as Source Indicators of Organic Matter Provenance in Estuarine Systems: Evidence from the Tay Estuary, Scotland, Estuar. Coast. Shelf Sci., 38, 219-233, https://doi.org/10.1006/ecss.1994.1015, 1994.

Tillin, H. M., Hiddink, J. G., Jennings, S., and Kaiser, M. J.: Chronic bottom trawling alters the functional composition of benthic invertebrate communities on a sea-basin scale, Mar. Ecol. Prog. Ser., 318, 31-45, https://doi.org/10.3354/meps318031, 2006.

Tyberghein, L., Verbruggen, H., Pauly, K., Troupin, C., Mineur, F., and De Clerck, O.: Bio-ORACLE: a global environmental dataset for marine species distribution modelling, Glob. Ecol. Biogeogr., 21, 272-281, https://doi.org/10.1111/j.14668238.2011.00656.x, 2012.

van de Velde, S., Van Lancker, V., Hidalgo-Martinez, S., Berelson, W. M., and Meysman, F. J. R.: Anthropogenic disturbance keeps the coastal seafloor biogeochemistry in a transient state, Sci. Rep.-UK, 8, 5582, https://doi.org/10.1038/s41598-018-23925-y, 2018.

Velinsky, D. J., and Fogel, M. L.: Cycling of dissolved and particulate nitrogen and carbon in the Framvaren Fjord, Norway: stable isotopic variations, Mar. Chem., 67, 161-180, https://doi.org/10.1016/S0304-4203(99)00057-2, 1999.

van der Voort, T. S., Blattmann, T. M., Usman, M., Montluçon, D., Loeffler, T., Tavagna, M. L., Gruber, N., and Eglinton, T. I.: MOSAIC (Modern Ocean Sediment Archive and Inventory of Carbon): A (radio)carbon-centric database for seafloor surficial sediments, Earth Syst. Sci. Data Discuss. [preprint], https://doi.org/10.5194/essd-2020-199, in review, 2020.

van Weering, T. C. E., Berger, G. W., and Okkels, E.: Sediment transport, resuspension and accumulation rates 
in the northeastern Skagerrak, Mar. Geol., 111, 269-285, https://doi.org/10.1016/0025-3227(93)90135-I, 1993.

Van Weering, T. C. E.: Recent Sediments and Sediment Transport in the Northern North Sea: Surface Sediments of the Skagerrak, in: Holocene Marine Sedimentation in the North Sea Basin, edited by: Nio, S.-D., Schüttenhelm, R. T. E., and Van Weering, T. C. E., Spec. Publ. Int. Assoc. Sedimentol., 5, 335-359, John Wiley \& Sons, Ltd., Chichester, UK, 1981.

Williams, M. E., Amoudry, L. O., Brown, J. M., and Thompson, C. E. L.: Fine particle retention and deposition in regions of cyclonic tidal current rotation, Mar. Geol., 410, 122-134, https://doi.org/10.1016/j.margeo.2019.01.006, 2019.

Wilson, R. J., Speirs, D. C., Sabatino, A., and Heath, M. R.: A synthetic map of the north-west European Shelf sedimentary environment for applications in marine science, Earth Syst. Sci. Data, 10, 109-130, https://doi.org/10.5194/essd-10-109-2018, 2018.
Zarate-Barrera, T. G. and Maldonado, J. H.: Valuing Blue Carbon: Carbon Sequestration Benefits Provided by the Marine Protected Areas in Colombia, Plos One, 10, e0126627, https://doi.org/10.1371/journal.pone.0126627, 2015.

Zhang, W., Wirtz, K., Daewel, U., Wrede, A., Kröncke, I., Kuhn, G., Neumann, A., Meyer, J., Ma, M., and Schrum, C.: The Budget of Macrobenthic Reworked Organic Carbon: A Modeling Case Study of the North Sea, J. Geophys. Res.-Biogeosci., 124, 14461471, https://doi.org/10.1029/2019JG005109, 2019.

Zuo, Z., Eisma, D., and Berger, G. W.: Recent sediment deposition rates in the oyster ground, North Sea, Netherlands J. Sea Res., 23 263-269, https://doi.org/10.1016/0077-7579(89)90047-1, 1989. 